\title{
A reprodução de velhos paradigmas em políticas de transporte e mobilidade: uma análise da região metropolitana de Florianópolis
}

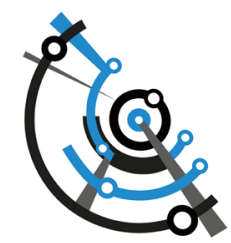

(1) Rodrigo Giraldi Cocco

Departamento de Geociências, Universidade Federal de Santa Catarina, Brasil.

Recibido: 2 de abril de 2018. Aceptado: 25 de octubre de 2018 .

\begin{abstract}
Resumo
As políticas de mobilidade urbana na Região Metropolitana de Florianópolis (RMF) têm sido afetadas por atributos inerentes à sua formação sócio-espacial. A estrutura política e as instituições de planejamento e gestão conformam uma superestrutura derivada de relações sociais conservadoras, sedimentadas no Estado e na sociedade civil, cujo resultado territorial se reflete na materialização de paradigmas de planejamento já superados, aprofundando as contradições entre território e mobilidade. Tais propostas tentam emular intervenções que obtiveram sucesso em outros contextos e temporalidades sem, no entanto, resolver contradições singulares do sistema de transporte público florianopolitano. As instituições de planejamento omitem-se em tocar nas estruturas de poder formadas entorno dos transportes públicos e do setor imobiliário. Assim, intervenções baseadas na concepção de um espaço conectivo ignoram que os transportes são apenas parte de uma política mais ampla de mobilidade. Desconsideram também a necessidade de uma política de mescla de usos do solo, de subsídios aos transportes públicos, de integração de distintas tecnologias de transporte e integração interinstitucional entre os organismos de planejamento. Nesse contexto, a vocação desse subespaço litorâneo catarinense para as mobilidades não-motorizadas, para os transportes marítimos e ferroviário leve - derivada da urbanização portuguesa, compacta e encravada em promontórios marítimos - é surpreendentemente negligenciada.
\end{abstract}

\section{The reproduction of old paradigms in public transportation and mobility policies: analysis applied to Florianopolis metropolitan region}

\footnotetext{
Abstract

Urban mobility policies in Florianopolis Metropolitan Region (FMR) have been affected by aspects inherent to their socio-spatial formation. The political structure, as well as planning and management institutions comprise a superstructure that derives from
}

\section{Palavras-chave}

Formação sócio-espacial Questão institucional Planejamento Mobilidade e Transportes
Keywords

Socio-spatial formation Institutional issues Planning Mobility and Transport 
conservative social relations rooted both in State and in civil society. Such relations result in the materialization of obsolete planning paradigms and in deepening the contradictions between territory and mobility. These assumptions aim at emulating interventions that have succeeded in other contexts and times, although they did not solve singular contradictions in the FMR public transportation system. Planning institutions avoid interfering in power structures built around the real estate industry and public transportation systems. Thus, interventions based on the design of connective spaces ignore that transportation is just part of a broader mobility policy; they also disregard the need of developing a policy focused on land-use mix, on subsidies to public transportation, on integrating different transport technologies and on the inter-institutional integration of planning agencies. Therefore, the potential of the aforementioned Santa Catarina State coastal sub-space for non-motorized motilities, as well as for catamaran and light rail transit - which derive from the compact and promontory-embedded Portuguese urbanization -, is surprisingly neglected.

\section{Introdução}

A RMF deriva de uma formação sócio-espacial cujo resultado em termos de urbanização e produção do espaço é muito peculiar. Essa combinação remonta à estratégia de colonização portuguesa; passando pela forma de partilha de lotes dos imigrantes açorianos e; pelo modelo de colonização, de produção e reprodução inaugurado pelos imigrantes alemães no interior da região. Passa também pelo quadro físico regional; pela centralidade da Ilha de Santa Catarina em relação à região e a ação do próprio Estado, que na segunda metade do século XX estimulou ainda mais a centralidade insular, gerando uma rede urbana regional marcada pela concentração de fluxos em direção a um espaço cuja acessibilidade é restrita às Pontes Pedro Ivo Campos e Colombo Machado Salles, sem acessos exclusivos para transporte público. Congestionamentos na rodovia BR-101 - relacionados à configuração da rede urbana estadual - também incrementam tempos de deslocamento de motoristas e passageiros do transporte público que efetuam deslocamentos pendulares entre cidades da região metropolitana.

Além desses problemas do espaço florianopolitano, poucas ações contundentes desde o Estado têm sido direcionadas a conter uma urbanização recente que beira o laissez-faire - comandada pelos agentes do mercado imobiliário - que determina a topologia, os ritmos e as qualidades do espaço construído. Na última década, municípios metropolitanos como Palhoça, promoveram forte expansão urbana dispersa voltada a segmentos sociais de média e baixa renda, em função de uma combinação de elementos físicos e sócio-espaciais. Por outro lado, produtos imobiliários de luxo concentram-se nos espaços melhor dotados de infraestrutura e acessibilidade, resultando em um contexto de grande acessibilidade às principais centralidades regionais para as altas rendas e, por outro lado, a interiorização - e com ela a necessidade de commutings - dos segmentos sociais de baixa renda.

Vale ressaltar que pouco mais de $10 \%$ das populações dos municípios metropolitanos de Palhoça, Antônio Carlos, Celso Ramos, Santo Amaro da Imperatriz e Águas Mornas, levam mais de uma hora e até duas horas, em seus deslocamentos pendulares casa-trabalho (Cocco, 2017). Tratam-se, portanto, de três a quatro horas diárias improdutivas, dispendidas na mobilidade. Em face a problemas como esses - resultantes de um acumulo histórico de contradições não resolvidas -, as recentes intervenções viárias e proposições em transportes, têm se mostrado insuficientes, já que não têm sido capazes de melhorar as condições de mobilidade por transporte público, e menos ainda, modificar a matriz modal regional significativamente.

\section{Palabras clave}

Formación socio espacial Cuestión institucional Planeamiento Movilidad y Transportes 
A questão à qual conferimos centralidade refere-se ao fato de que as especificidades do espaço construído e do quadro físico da Região Metropolitana de Florianópolis, conferem grande complexidade espacial à região, a qual exigiria a presença de instituições de planejamento metropolitano eficazes, capazes de operar de modo inovador em meio a essa complexidade. Contudo, são justamente entraves na esfera político-econômica e institucional que acabam inviabilizando ações de planejamento mais contundentes. Esses entraves se ramificam na: 1) falta de integração interinstitucional; 2) defasagem do pessoal de planejamento; 3) regime de atuação das autarquias defasado; 4) sobreposição contraditória de jurisdições institucionais; 5) ingerência de atores privados sobre concepções e ações de planejamento e; 6) ausência de autonomia financeira e/ou um projeto estratégico de financiamento das autarquias de planejamento e gestão.

Além disso, essas incongruências estão longe de serem compreendidas pela população em geral e, na esteira dessas debilidades institucionais, a estrutura política conservadora - que não intenciona a implementação de mudanças profundas nas instituições -, tem feito um uso político das "novas" proposições em transportes e mobilidade, apenas falseando ações que deveriam se cristalizar em verdadeiras estratégias TOD (Transit Oriented Development) (Cervero \& Dai, 2014). Ou seja, sem investigações profundas sobre o território, busca-se apenas plasmar no espaço regional, modelos standard de sistemas de transporte. Nesse contexto, acirram-se ainda mais as contradições entre os transportes e as demandas por mobilidade, haja vista a incompletude, fragmentação e desqualificação na qual esses programas têm sido implementados. Consoante esse debate, analisaremos, de modo breve, as principais contradições histórico-geográficas entre o espaço regional da RMF, os sistemas de transporte e as condições de mobilidade. A partir desse marco geo-histórico, analisaremos como essas incongruências se perpetuam nos projetos, proposições e realizações recentes, ora como resultado de ingerência da iniciativa privada em ações core de planejamento - em face à fragilidade e permeabilidade das instituições públicas -, ora como resultado da práxis das estruturas conservadoras de poder, entronizadas no Estado de Santa Catarina e, especificamente, em sua Região Metropolitana.

\section{Marco teórico para uma análise dos transportes e da mobilidade no contexto latino-americano}

O presente artigo demandou um reexame das teorias e métodos em transportes e mobilidade urbana. Consoante as renovações de enfoque mais recentes, definimos os transportes urbanos como os meios criados em função de um padrão histórico de evolução fragmentada das cidades (Miralles-Guasch, 2002:12). Já a mobilidade, representa a soma dos deslocamentos individuais cotidianos, que variam em velocidade, distância, frequência, motivos, entre outros aspectos, segundo a heterogeneidade dos grupos sociais (Miralles-Guasch, 2002; Banister, 2008), ou seja, são atributos daqueles que se movem. Em complementaridade a essas definições, a mobilidade é composta por viagens materiais e imateriais, virtuais e euclidianas, ou seja, viagens reais, pensadas e possíveis. Em outras palavras, o deslocamento feito é realizado segundo as condições materiais disponíveis, mas isso não quer dizer que essa é a dimensão plena do conceito de mobilidade, a sua totalidade. ${ }^{1}$

Os transportes e a mobilidade também interferem na experiência do uso do espaço, na própria produção do espaço e, assim, nas condições para uma possível ruptura dos baixos padrões de produção e reprodução social presentes na periferia do capitalismo. Assim sendo, políticas públicas que se autodenominam de vanguarda, devem conceber políticas de mobilidade que superem a mera oferta

1. Nesse caso, ao reduzir a mobilidade à viagem representável cartograficamente, a realidade da viagem é conhecida apenas parcialmente (Gutiérrez, 2012). Assim, o campo de estudos da mobilidade deve reconhecer um universo analítico de viagens que abarque também as viagens que determinado grupo social conhece, aquelas que esse mesmo grupo considera possíveis de fazer diante da oferta de acessibilidade e aquelas efetivamente realizadas. Essa abordagem corrobora com nossas analises, uma vez que na pesquisa se pode depreender desníveis profundos entre a proposição do planejamento institucionalizado e as mobilidades dos grupos sociais. Esses desajustes refletem uma clivagem entre a representação política e o Estado - que deveriam zelar pelo interesse popular - e os interesses de fato, da população. 
quantitativa de transporte público ou de infraestrutura viária. Devem adaptar-se às demandas diversas dos diferentes grupos sociais e não o contrário. Devem, inclusive, dar vazão aos anseios dos diferentes grupos sociais envolvidos no ato do planejamento, resolvendo impasses na participação popular. É importante salientar que a participação popular no planejamento dos transportes e da mobilidade é relativamente diversa da participação no planejamento urbano stricto sensu. No caso daquela, exige a liderança popular de um intelectual orgânico ${ }^{2}$ que conheça em nível de detalhe as propostas técnicas, evitando que a população seja persuadida prontamente a aceitá-las.

Há, ademais, uma relação dialética existente entre a qualidade da oferta e a experiência coletiva dos usuários dos transportes públicos. Esses usuários, ao utilizarem o produto-serviço transporte, criam, a partir dessa experiência, uma referência de qualidade (Jaramillo, 1983:14). O fato contundente é que os agentes que hegemonizam a produção do espaço - nesse caso, o Estado e as estruturas de poder que o controlam, assim como agentes privados interessados em auferir vantagens econômicas - podem efetuar um uso ideológico-político dos projetos de transporte (Figueroa \& Orellana, 2007), especulando com a baixa referência de qualidade sedimentada historicamente entre os usuários desses serviços. Para Jaramillo (1983) e Figueroa (2007), esse é o cenário que se apresenta, em geral, nos países latino-americanos e é uma das razões pelas quais se perpetua a baixa qualidade dos equipamentos para a mobilidade. Obviamente, ancorada em um crescimento econômico insuficiente. Crescimento esse, quando é significativo - por exemplo, nos ciclos de aumento dos preços internacionais das commodities - não encontra canais pelos quais chegue ao planejamento da mobilidade e dos transportes, em parte, pela fragilidade destas instituições.

Ademais, a baixa expectativa da população com relação à qualidade do serviço facilita ao Estado - ocupado por camadas conservadoras da elite nacional - e a agentes privados, como operadores de transporte público e consultorias desejosas de oferecer serviços, disponibilizar serviços de menor qualidade e sob menor custo para o capital executor, sem que seu efeito social seja intolerável e gere respostas políticas de grande envergadura por parte dos usuários desses valores de uso coletivos (Jaramillo, 1983). Essa dinâmica se coaduna ao avanço das lógicas neoliberais para dentro do Estado e de suas instituições, as quais não agem no sentido de promover rupturas nos padrões anteriores de planejamento. Essas rupturas são entendidas, nessa lógica, como meros gastos a uma demanda não solvável (Paget-Seekins, 2015) e, portanto, desnecessários - do ponto de vista dessas elites -, ao nível das forças produtivas presentes nesses espaços. Tal problemática nos remete ao debate marxiano sobre desenvolvimento e distribuição.

A categoria de distribuição, em Marx (2011), representa a distribuição de meios de reprodução social, ou seja, uma determinada quantidade e qualidade de víveres, mas também de equipamentos de educação, cultura, moradia, saúde - e, inclusive transportes e mobilidade - que possibilitam a determinado segmento social sua reprodução enquanto tal. Essa distribuição varia em quantidade e qualidade, segundo as exigências de produtividade de cada modo de produção dominante - assim como de diferentes estágios de um mesmo modo de produção, tornado concreto em uma formação sócio-espacial. Ou seja, cada trabalhador recebe seu quinhão (cesta de consumo), segundo o nível de exigência sobre a força de trabalho, que provem de uma determinada formação sócio-espacial (Santos, 1982). As superestruturas (leis, instituições, cultura etc.) criadas para referendar essas relações de produção são reafirmadoras dessas relações. O conteúdo social e político dessas superestruturas é essencial para entender a práxis que provém delas, corporificada em seus agentes. No caso específico do planejamento, o preenchimento das instituições por intelectuais orgânicos à sua coletividade (Gramsci, 1968), representaria a consolidação de
2. A categoria gramsciana de intelectual orgânico se refere àquelas lideranças que detêm consciência de classe, interesses de classe e podem, assim, conduzir no sentido do desenvolvimento e da autoconsciência, a massa à qual devem diligência, independentemente de serem letrados ou não. Ele é também fruto das contradições, sendo produzido diretamente por esses grupos populares e se distingue, assim, dos intelectuais tradicionais. Os intelectuais tradicionais, cujo domínio advêm de uma base industrial restrita (que não produziu superestruturas mais complexas, no caso latino-americano), são aqueles que conferem guarida ao status quo, quase sempre expondo uma origem ligada às velhas oligarquias ou aos interesses externos privados, em detrimento do interesse nacional (Gramsci, 1968:31). No caso da mobilidade urbana, em se tratando de um setor intensivo em inovação tecnológica e organizacional, quando não há intelectuais-orgânicos conhecedores do tema junto à população, é comum que agentes privados atuem através de intelectuais de tipo tradicional, com o objetivo de produzir narrativas que enaltecem artificialmente a qualidade desta ou daquela tecnologia. 
um novo bloco de interesses proativo - adaptando a uma escala geográfica menor a categoria de bloco histórico (Portelli, 1977) - no sentido de conduzir as políticas de mobilidade, transportes e produção do espaço, segundo as necessidades e desejos concretos das classes sociais e grupos marginalizados. Em nosso entendimento, esse ferramental teórico-conceitual contribui com as análises desse trabalho, na medida em que permite relacionar processos mais amplos, na escala do modo de produção, da formação social e das superestruturas em geral, a processos mais específicos e setoriais, como é o caso das instituições de planejamento da mobilidade.

\section{Metodologia}

O presente artigo foi elaborado mediante uma metodologia mista, ou seja, qualitativa e quantitativa, baseada na compilação e análise de dados quantitativos relativos aos sistemas de transporte da RMF, mas também elementos do discurso (Røe, 2000). É comum em trabalhos envolvendo transportes, o emprego isolado de metodologias quantitativas ou qualitativas. No entanto, estas abordagens são muito limitantes para a explicação de fenômenos que exigem, por um lado, exibir as contradições entre transporte e território e, por outro, analisar as narrativas que se constroem sobre esse quadro. No que se refere à parte quantitativa, a mesma pautou-se na busca, elaboração e análise de dados on-line, bem como dados presentes em relatórios e estudos, junto a empresas privadas e instituições públicas. Esses dados resultaram nas tabelas, gráficos e mapas utilizados nesta publicação. A parte qualitativa pautou-se em entrevistas em profundidade direcionadas a agentes-chave na RMF e na Europa.

Na RMF, foram, ao todo, 24 entrevistas, sendo 4 em empresas operadoras de transporte público; $3 \mathrm{em}$ sindicatos de empresas de transporte; 1 no sindicato de trabalhadores do setor de transportes públicos; 7 em instituições de planejamento de transporte público; 1 em instituições de planejamento de infraestrutura; 4 ligadas ao setor imobiliário; 1 na associação de municípios da região; 1 a um político da região; $1 \mathrm{a}$ um antigo funcionário da Prefeitura de Florianópolis e; $1 \mathrm{com}$ dois auditores fiscais do Tribunal de Contas do Estado de Santa Catarina. Com o objetivo não de comparar territórios, mas políticas públicas, efetuamos também 11 entrevistas no exterior, sendo que 8 delas foram realizadas em Barcelona (Espanha), com técnicos e executivos das autarquias e empresas públicas, operadoras e gestoras dos transportes públicos da Área Metropolitana de Barcelona; 1 na cidade de Santa Coloma de Gramanet (Espanha), na qual foi entrevistado um executivo da empresa Alstom, na planta produtora dos VLTs Citadis; 1 em Madri, na autoridade de transportes regionais, e outras 2 com técnicos dos transportes públicos de Bolonha (Itália). As entrevistas foram realizadas entre os anos de 2014 e $2016 .^{3}$

Quanto ao perfil dos entrevistados, tratam-se de coordenadores e arquitetos de associações de municípios; fiscais ligados às autarquias de planejamento; técnicos e executivos de autarquias ligadas ao planejamento da mobilidade urbana; auditores fiscais; secretários municipais de secretarias de desenvolvimento urbano e habitação; técnicos e chefia das autarquias metropolitanas de planejamento e; gerentes de logística e frota das empresas operadoras privadas de transporte público. As temáticas e assuntos tratados nas entrevistas variaram conforme o entrevistado, mas de modo geral, foram levantadas questões relativas à: relação público-privado nos transportes; os principais problemas em termos de transporte e mobilidade no recorte de estudo na percepção do entrevistado; as inovações e deficiências institucionais na opinião do entrevistado e; as principais razões das deficiências no planejamento urbano e de transporte públicos na Região.
3. Os casos europeus, principalmente o caso espanhol, foram escolhidos no âmbito da realização de estágio no exterior e assim, a possibilidade de aprofundamento do debate comparativo, entre as políticas públicas implementadas em países europeus e aquelas desenvolvidas em países latinoamericanos. Além disso, cidades como Barcelona e Madri passaram pela transição de um sistema de transporte público não subsidiado e sem autarquias metropolitanas, para um sistema altamente subsidiado e dotado de instituições públicas centralizadoras-distribuidoras dos recursos, que passaram a funcionar também como rótulas de gestão, contabilidade e planejamento dos transportes. Assim, são casos que podem enriquecer o debate dessa problemática no Brasil. 
A opção metodológica por efetuar entrevistas em profundidade com agentes-chave, se deu por uma demanda do próprio objeto da pesquisa. Nesse caso, trata-se de uma análise das instituições de planejamento e dos projetos em transportes e mobilidade, a qual se caracteriza como uma análise de oferta de serviços e infraestruturas. Quanto à forma de apresentação dos resultados metodológicos, não empregamos a forma da citação direta de entrevistas, mas paráfrases, interpretações e análises de informações expostas pelos entrevistados.

\section{Formação sócio-espacial regional e contradições entre transporte, mobilidade e território}

A Região Metropolitana de Florianópolis conforma um espaço cujo quadro físico é limitante a formulações pré-concebidas de planejamento. A escolha do sitio fundacional de Nossa Senhora do Desterro (século XV) - denominação dada à atual Florianópolis até fins do século XIX - remonta à estratégia de colonização portuguesa, que era também uma estratégia de defesa territorial. É a partir dessa dupla concepção que os colonizadores elegem um promontório insular junto ao mar para fundar o núcleo urbano da atual Florianópolis (Lobo e Simões Júnior, 2012). Não obstante, o complexo de formações naturais que outrora eram estratégicos para a contenção de invasores, passa a ser uma especificidade que exige um planejamento urbano e da mobilidade igualmente singulares. No que se refere à mobilidade, a presença de mangues, restingas, baías, morros, lagos, rios, canais e a própria condição insular da cidade principal, exigem uma mescla de tecnologias de transporte e mudanças nos usos do solo, que as instituições de planejamento não estão dispostas a implementar. O Mangue do Itacorubi, por exemplo, é um elemento de segregação entre a área central insular de Florianópolis e os populosos bairros do norte da Ilha, cujo único acesso é a rodovia SC-401. Além disso, há maciços que se interpõem entre os assentamentos, como é o caso do Morro da Cruz, estabelecido entre distritos populosos como Trindade, Itacorubi e Centro.

O próprio alargamento das rodovias de ligação dos balneários é dificultado por estas formações adjacentes, como se evidencia no Morro do Maurício, na entrada para o bairro Ingleses, ao norte da Ilha. As infraestruturas de ligação mais pesadas, como túneis, pontes e elevados, também tiveram (e ainda tem) seus custos bastante elevados devido à presença destas formações naturais. Vale ressaltar que o próprio isolamento relativo dos núcleos populacionais, na história da região, se deve a essas barreiras geográficas, mas, por outro lado, também foi determinado pela tradição açoriana, na medida em que suas populações rurais e costeiras tradicionalmente comercializavam apenas o excedente da pequena unidade de produção (Silva, 1992). Outra importante rugosidade proveniente da tradição açoriana que influencia o quadro da mobilidade são as vias estreitas e extensas, denominadas servidões, intercaladas de poucas vias de maior capacidade (Figura 1 ). ${ }^{4} \mathrm{Na}$ medida em que essas vias não formam uma quadrícula, mais se assemelhando a uma "espinha de peixe" - ou seja, vias compridas e sem acesso lateral entre as mesmas, desembocando na avenida do bairro ou na rodovia - $\mathrm{o}$ planejamento tradicional baseado apenas em modos de transporte motorizados não surte o efeito desejado. 


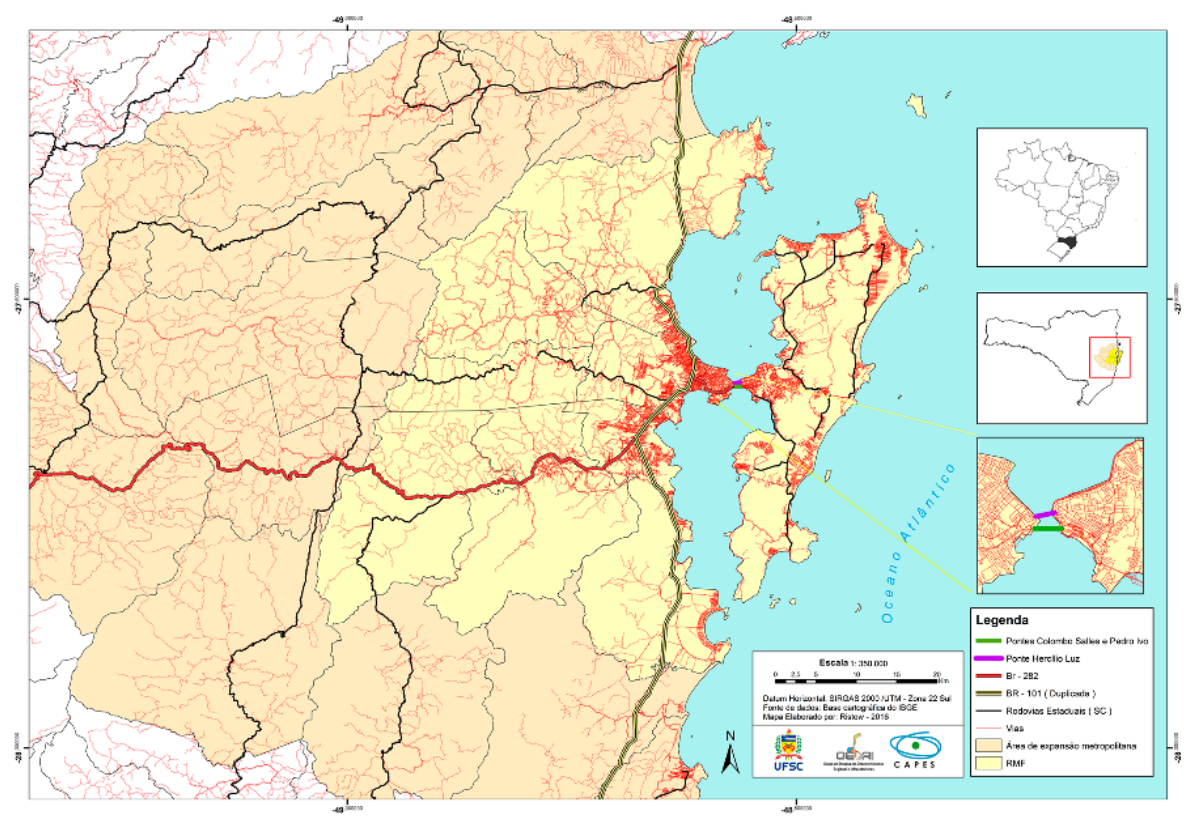

Figura 1. Sistema viário da Região Metropolitana de Florianópolis. Fonte - Elaboração própria (2016).

No tocante às centralidades, nota-se que a involução da pequena produção mercantil açoriana (Campos, 1991), deflagrou na constituição de uma baixa quantidade de capitais comerciais e industriais - e assim, em um primeiro momento, pouca diversidade de polos geradores de mobilidade - com origem nos espaços açorianos da região. Soma-se a isso, o fato de que historicamente, à Região Metropolitana de Florianópolis é conferido um caráter muito mais administrativo do que de espaço de produção. Assim, sob patrocínio do Estado, instalam-se a partir de 1950, diversos equipamentos públicos ligados à gestão e ao planejamento, todos eles localizados no sítio fundacional da cidade, na Ilha. A instalação desses equipamentos motivou que, ao seu redor, surgissem também centralidades da iniciativa privada, consolidando definitivamente o promontório oeste da Ilha, como o maior polo de destinos da região. Uma maior difusão de centralidades ao longo de toda a região ocorreria, em certa medida, a partir da expansão de capitais comerciais, industriais e de serviços - grande parte deles com origem em outras cidades do estado - oriundos das pequenas produções italianas e alemãs. São esses, redes de lojas de móveis, supermercados, eletrodomésticos, materiais de construção, entre outros, que se instalam em função das novas demandas advindas do crescimento populacional posterior às novas edificações públicas - tanto dos operários construtores, que passam a residir na região, quanto dos novos funcionários públicos (Peluso Júnior, 1991).

Como resultado desse contexto, já na década de 1980, observava-se uma divisão de viagens por transporte público que se concentrava entre os municípios de Palhoça, São José, Biguaçu e Florianópolis. Assim, 59\% das viagens por transporte coletivo originadas em Palhoça, ocorriam entre Palhoça e a capital Florianópolis, 24\% para outros municípios (São José e Biguaçu) e apenas $17 \%$ se davam internamente à cidade de Palhoça. Com origem em Biguaçu, $62 \%$ das viagens se davam entre a cidade e a capital, $31 \%$ entre as demais e apenas $7 \%$ no espaço intraurbano de Biguaçu. Finalmente, a partir de São José, $84 \%$ das viagens ocorriam entre esta cidade e a capital, 7\% com as demais e 9\% no seu espaço interno (Empresa Brasileira de Planejamento de Transportes, 1978). A figura abaixo (Figura 2) exibe os destinos e as intensidades dos fluxos cotidianos de transporte público originados em Palhoça, em direção às demais cidades, no final da década de 1970. 


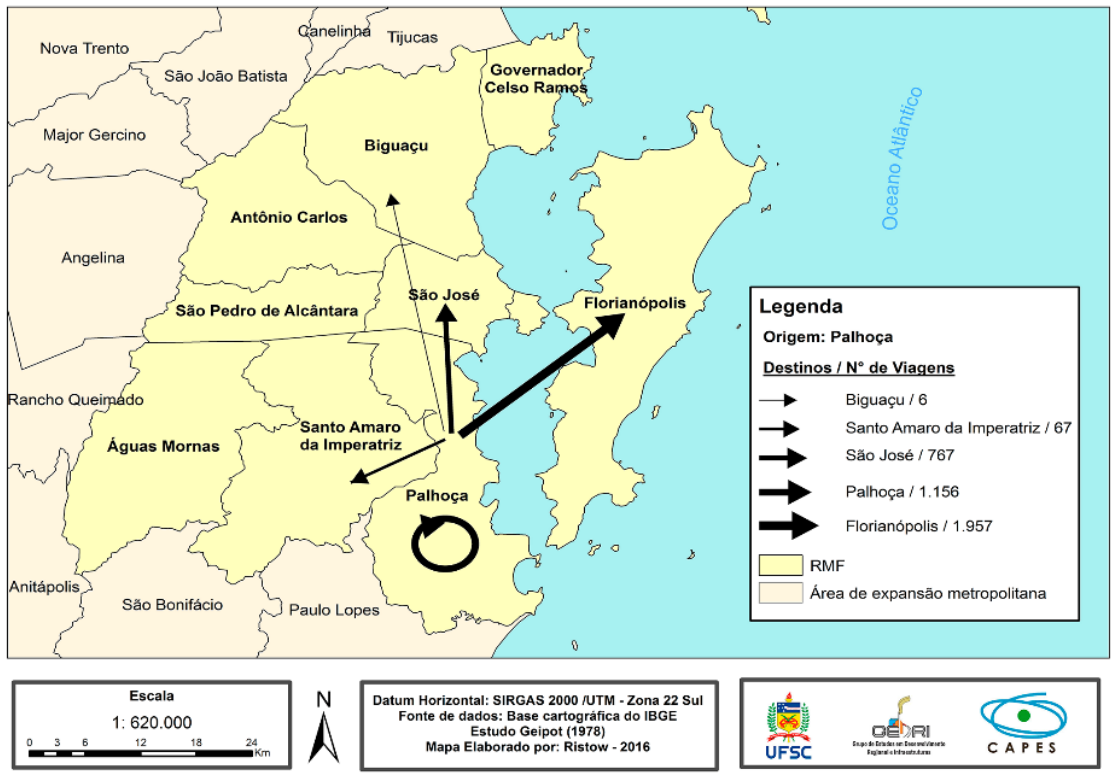

Figura 2. Fluxos de passageiros de transporte público com origem em Palhoça, na RMF, em 1978. Fonte: Empresa Brasileira de Planejamento de Transportes (1978).

Atualmente, apesar da complexificação do quadro de origens e destinos e do próprio espaço regional, o subespaço central de Florianópolis ainda é aquele que mais atrai fluxos, pressionando significativamente o sistema viário regional, isto é, as pontes entre o espaço continental e o espaço insular e as rodovias estaduais e federais. Como se pode observar (Figura 3), embora se verifique maior diversidade de destinos no espaço regional, Florianópolis - no conjunto de sua parte insular, somada à sua parte continental - segue sendo o destino preferencial de fluxos. Mais do que isso, a centralidade de Florianópolis amplia-se cada vez mais, inclusive ancorada em políticas públicas. Os fluxos que se dirigem a Florianópolis são provenientes dos 9 municípios que conformam a RMF, quais sejam, Águas Mornas, Antônio Carlos, Biguaçu, Florianópolis, Palhoça, Santo Amaro da Imperatriz, São José, São Pedro de Alcântara e Governador Celso Ramos. Contudo, na figura abaixo (Figura 3), exibimos apenas as origens de fluxos a partir de Palhoça.

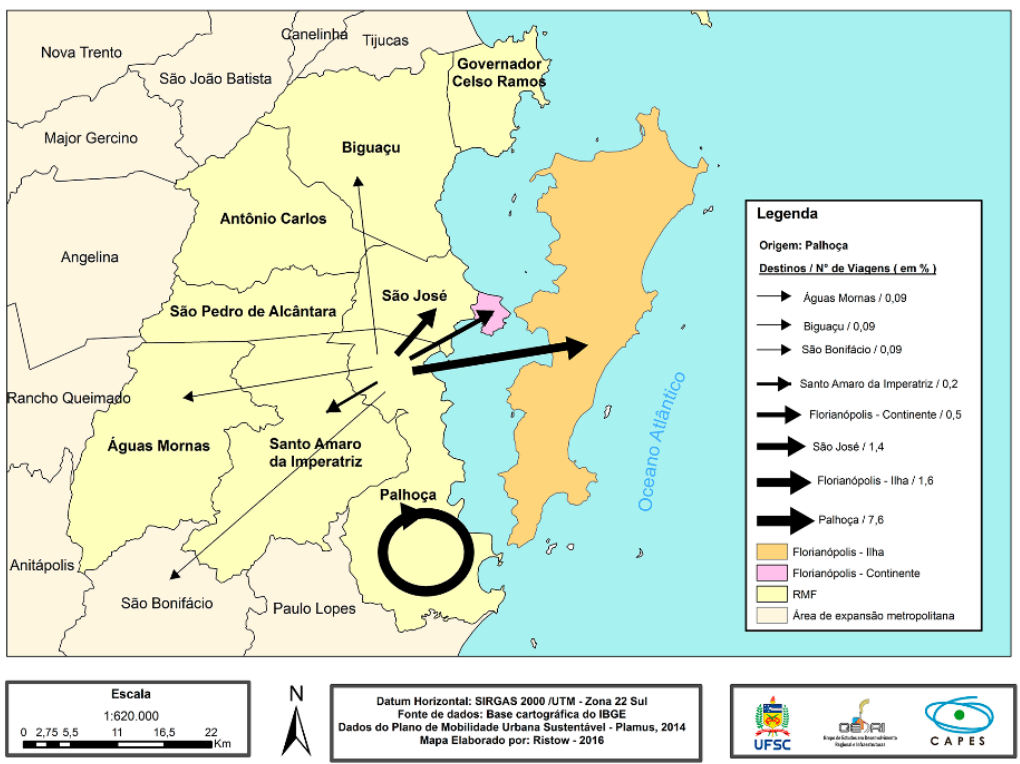

Figura 3. Fluxos de passageiros de transporte público com origem em Palhoça, na RMF, no ano de 2014. Fonte: Consórcio Logit Strategy (2014). 
Nota-se que em sua área continental, a região possui municípios extensos territorialmente, com manchas urbanas descontínuas (Figura 3), mas com pequena população (Quadro 1). Além disso, as populações com empregos (e, portanto, os polos de atividades) concentram-se nos municípios da área conturbada, ou seja, Florianópolis, São José, Biguaçu e Palhoça, mas Florianópolis emprega mais do que a soma desses três municípios vizinhos. Finalmente, em reforço a essas análises, observa-se que a Ilha - concentradora de atividades, empregos e população -, é o único espaço que mais atrai do que gera fluxos (Quadro 1), ou seja, há uma alta densidade de fluxos regionais pendulares, que se afunilam nas pontes e na truncada rede viária insular diariamente. Florianópolis gera 862.142 viagens e atrai 1.125 .382 viagens diariamente. Com exceção dos municípios de Biguaçu, São José e Palhoça, observa-se que os demais municípios geram (produzem) e recebem (atraem) menos viagens. Alguns municípios como Angelina e Rancho Queimado, recebem 2.546 viagens diárias em média, pois há muita ocorrência de segundas residências, visitas familiares etc. Assim mesmo, ocorrem congestionamentos entre estes municípios e a Ilha - e também entre esses e os demais municípios da área conturbada -, inclusive pelo fato de que o sistema viário é insuficiente e o uso do automóvel é intenso. Apesar da centralidade da ilha, São José atrai $18 \%$, Palhoça, $11,46 \%$ e Biguaçu 3,51\% das viagens, o que reflete que com o passar do tempo, a região se complexificou. Essa complexificação, no entanto, não significou uma transformação absoluta dos padrões de pendularidade continente-ilha.

Quadro 1. Evolução da população, área municipal, densidades e empregos e atividades econômicas dos municípios da RMF. Fonte: Instituto Brasileiro de Geografia e Estatística, IBGE (2010); Plamus (2014). *Representa a intensidade de fluxos diários de pessoas, em quantidade de viagens.

\begin{tabular}{|c|c|c|c|c|c|c|c|c|}
\hline \multirow{2}{*}{ Municípios } & \multirow{2}{*}{ Área $(\mathrm{km2})$} & \multicolumn{4}{|c|}{ Evolução da população (mil hab.) } & \multirow{2}{*}{$\begin{array}{c}\begin{array}{c}\text { População } \\
\text { empregada } \\
\text { (mil hab.) }\end{array} \\
2017\end{array}$} & \multirow{2}{*}{$\begin{array}{c}\begin{array}{c}\text { Viagens } \\
\text { atraídas* }\end{array} \\
2014\end{array}$} & \multirow{2}{*}{$\begin{array}{c}\begin{array}{c}\text { Viagens } \\
\text { geradas* }\end{array} \\
2014\end{array}$} \\
\hline & & 1991 & 2000 & 2010 & 2017 & & & \\
\hline Florianópolis & 438 & 255 & 342 & 421 & 485,8 & 316,5 & 1125,4 & 862,1 \\
\hline São José & 151 & 139,5 & 173,5 & 210,5 & 239,7 & 114,3 & 335,7 & 487,3 \\
\hline Palhoça & 395 & 68 & 103 & 137 & 164,9 & 44,9 & 171,4 & 205,1 \\
\hline Biguaçu & 374 & 34 & 48 & 58 & 66,5 & 14,5 & 62,5 & 112,3 \\
\hline $\begin{array}{l}\text { Santo Amaro da } \\
\text { Imperatriz }\end{array}$ & 344 & 13 & 16 & 20 & 22,6 & 6,1 & 17,5 & 32,3 \\
\hline $\begin{array}{l}\text { Governador Celso } \\
\text { Ramos }\end{array}$ & 117 & 10 & 11,5 & 13 & 14,2 & 2,7 & 28,1 & 37,9 \\
\hline Antônio Carlos & 229 & 5,6 & 6,4 & 7,4 & 8,3 & 2,5 & 15,3 & 19,4 \\
\hline Águas Mornas & 327 & 4,6 & 5,3 & 5,5 & 6,2 & 1,2 & 5,6 & 6,5 \\
\hline $\begin{array}{l}\text { São Pedro de } \\
\text { Alcântara }\end{array}$ & 139 & -Sem dado- & 3,5 & 4,7 & 5,6 & 0,6 & 0,8 & 3,9 \\
\hline Total & 2514 & 529,7 & 709,2 & 877,1 & 1013,8 & 503,3 & 1762,3 & 1766,8 \\
\hline
\end{tabular}

Considerando essa mesma base de dados, observa-se também que 25\% do total dos destinos de viagens são intermunicipais. Além disso, a maior parte dessas viagens se dirige aos municípios de maior porte da região, sendo $8 \%$ para Biguaçu, $12 \%$ para Palhoça, 35\% para São José e 37\% para Florianópolis. Nota-se que dos 37\% de viagens a Florianópolis, que correspondem a 165.000 passageiros por dia, 61\% desses passageiros se direcionam ao Centro, na Ilha, $16 \%$ à área continental da cidade (Estreito e arredores), $11 \%$ ao sul da ilha, $9 \%$ ao norte da ilha e 3\% ao leste da ilha. Entre os bairros e centralidades ao sul da Ilha há também importantes gargalos infraestruturais. Ressalta-se que esses deslocamentos se estruturaram, historicamente, pela edificação de polos geradores de tráfego com funções estatais, na parte insular e poucas funções na parte continental. 
Nos trajetos continente-ilha a situação pode ser mais severa, considerando que nos horários de pico o tráfego se afunila nas pontes e no truncado sistema viário que se estrutura em seu entorno, sem a presença de corredores exclusivos. Na recente pesquisa de contagem de tráfego - que integra a referida Pesquisa de O-D (origem destino) - se verificou que $75 \%$ dos veículos que ocupam as pontes são automóveis, $13 \%$ são motocicletas (estes, em conjunto, ocupam $90 \%$ da capacidade das pontes) e apenas 3\% são ônibus. Assim, os 240 veículos de transporte coletivo (ônibus) que atravessam as pontes diariamente, nos horários de pico, transportam 18.000 passageiros e, se fossem atrativos ao usuário de automóvel, poderiam retirar 6.200 automóveis/hora das pontes (Logit; Strategy et al., 2015).

$\mathrm{Na}$ alta temporada de verão, agregam-se os deslocamentos diários motivados por lazer. Ressalta-se que $60 \%$ destes deslocamentos se efetuam de automóvel, tornando ainda mais severa a condição dos usuários de ônibus. São, portanto, 14.000 banhistas deixando as praias nos horários de pico (entre as 18:00 e as 20:00 horas), a maioria deles utilizando automóvel. Desses, muitos optam por muitas horas de viagem em automóvel desde suas cidades, pois os dados da pesquisa apontam que 34\% destes turistas são de outros estados brasileiros, $26 \%$ são provenientes da própria Ilha, 19\% da RMF; 13,52\% de outros países, notadamente, de Argentina, Uruguai, Paraguai e; 7,31\% de outros municípios catarinenses (Logit; Strategy et al., 2015). Diante desse aumento de tráfego, observam-se esforços por parte do poder público e das classes que o controlam, em criar uma coesão social artificial a partir do city marketing do "turismo, carro-chefe da economia local". A contradição essencial, nesse caso, se dá na medida em que essas políticas públicas privilegiam projetos específicos para o turismo e para os empreendimentos imobiliários voltados às altas rendas (Jurerê Internacional). Esse é o caso das ampliações rodoviárias para o Norte da Ilha, que, inclusive, geraram barreiras à mobilidade dos moradores dos bairros adjacentes.

\section{O transporte privado individual e os transportes públicos na região metropolitana de Florianópolis}

Distintas cidades e regiões metropolitanas da Europa Ocidental lograram estabelecer uma proporção razoável entre usuários de transporte privado individual, usuários de modos não motorizados e usuários de transporte público. Isso ocorreu após décadas de esforços envolvendo o financiamento massivo de transportes públicos eficazes, assim como de infraestruturas de apoio à intermodalidade e aos modos não-motorizados. Foi possível, assim, gerar tempos de trânsito toleráveis, consoante um novo paradigma acerca da mobilidade, que abandonou a abordagem pretenciosa - pautada na ampliação massiva de sistema viário - de supressão absoluta dos congestionamentos (Banister, 2008).

Destarte, embora essas cidades conheçam um grande percentual de motorização de suas populações (automóveis por habitante), essa motorização não corresponde a um uso cotidiano do automóvel. Esse fenômeno é devido a um conjunto de serviços e infraestruturas de transporte público que, em determinados contextos é capaz de ser mais eficaz do que o próprio automóvel. Um dos elementos fundamentais para esse sucesso é a concretização de tempos razoáveis de deslocamento dos usuários - que não dependem da velocidade do meio de transporte, mas de sua conectividade - com menor participação do automóvel, embora possa ter o automóvel como parte da viagem. Entretanto, no caso da Região Metropolitana de Florianópolis, na ausência desses serviços e infraestruturas, associada a um descolamento entre a eficiência e a eficácia dos transportes públicos, o que se obtém é um sistema de transporte público pouco atrativo ao usuário de automóveis. Sistema que abarca, de modo cada vez mais evidente, uma área menor do subespaço regional, seja pela redução de linhas de transporte público ou de horários de atendimento dos serviços. 
O conceito de eficiência refere-se à eficiência econômica do sistema, a qual remete ao máximo aproveitamento dos fatores de produção disponíveis, em vista de determinada taxa de lucro. Já a eficácia, remete à sua eficácia no atendimento da demanda, enquanto serviço de utilidade pública. Embora um possa sobrepor-se ao outro, esses conceitos não são excludentes entre si (Fenstenseifer, 1981). Observam-se bairros da RMF que oferecem serviços com frequências muito reduzidas, visando apenas à eficiência econômica. O quadro abaixo elenca exemplos entre os subespaços da RMF que sofrem maior redução de frequência, penalizando o tempo de deslocamento do usuário (Quadro 2).

Quadro 2. Frequências do serviço de transporte público nos horários de pico da tarde e entrepicos, em bairros periféricos de Florianópolis, Palhoça, São José e Biguaçu, comparativamente às Áreas Centrais e Centros, em 2014. Fonte: Consórcio Logit Strategy (2015).

\begin{tabular}{|c|c|c|c|c|}
\hline \multirow{2}{*}{ Município } & \multirow{2}{*}{ Bairro } & \multicolumn{2}{|c|}{$\begin{array}{l}\text { Frequência de serviço em dias } \\
\text { laborais (ônibus/hora) }\end{array}$} & \multirow{2}{*}{$\begin{array}{l}\text { Percentual de } \\
\text { redução dos } \\
\text { horários nos } \\
\text { entrepicos (\%) }\end{array}$} \\
\hline & & \begin{tabular}{|l} 
Pico da \\
tarde
\end{tabular} & $\begin{array}{l}\text { Entrepicos } \\
\text { (headways) }\end{array}$ & \\
\hline \multirow{5}{*}{ Florianópolis } & Córrego Grande & 9 & 5 & 36 \\
\hline & Canasvieiras & 1 & o & 56 \\
\hline & Rio Tavares & 4 & 2 & 30 \\
\hline & Abraão & 3 & 2 & 44 \\
\hline & Centro & 2 & 1 & 56 \\
\hline \multirow[t]{6}{*}{ São José } & $\begin{array}{l}\text { Kobrasol e Campinas } \\
\text { (Área Central) }\end{array}$ & 22 & 16 & 28 \\
\hline & Forquilhas & 18 & 14 & 21 \\
\hline & Forquilhinhas & 8 & 7 & 11 \\
\hline & Sertão do Maruim & 4 & 2 & 39 \\
\hline & Serraria & 12 & 10 & 11 \\
\hline & Areias & 3 & 1 & 56 \\
\hline \multirow{6}{*}{ Palhoça } & Aririú & 5 & 3 & 23 \\
\hline & Barra do Aririú & 24 & 14 & 39 \\
\hline & Guarda do Cubatão & 7 & 4 & 35 \\
\hline & Centro & 12 & 7 & 38 \\
\hline & São Sebastião & 7 & 5 & 25 \\
\hline & Terra Nova & 2 & o & 70 \\
\hline \multirow{5}{*}{ Biguaçu } & Pacheco & 1 & o & 100 \\
\hline & Morro do Gato & 6 & 3 & 41 \\
\hline & Jardim Janaína & 7 & 5 & 29 \\
\hline & Prado & 1 & $\mathrm{o}$ & 100 \\
\hline & Centro & 5 & 4 & 24 \\
\hline
\end{tabular}

Como podemos observar no quadro (Quadro 2) acima, nos espaços periféricos dos municípios da RMF, os percentuais de redução de serviço de transporte público (horários) variam de $11 \%$ a até $100 \%$, enquanto as Áreas Centrais possuem uma margem com menor amplitude, entre $24 \%$ e $56 \%$. Ora, tal contexto penaliza fortemente o tempo de deslocamento do usuário de transporte público, bem como do usuário dos demais modos de transporte, já que há uma relação lógica entre não-atratividade do transporte público, uso exponencial do automóvel, congestionamento e incremento geral dos tempos de deslocamento (Quadro 3). 
Quadro 3. Tempos gerais de deslocamento para o trabalho em bairros dos municípios conturbados da RMF, em 2010. Fonte: IBGE (2010).

\begin{tabular}{|c|c|c|c|c|c|c|}
\hline Município & Bairro & $\begin{array}{c}5 \text { minutos } \\
(\%)\end{array}$ & $\begin{array}{c}6 \text { a } 30 \\
\text { minutos } \\
(\%)\end{array}$ & $\begin{array}{l}30 \text { minutos } \\
\text { a1 hora (\%) }\end{array}$ & $\begin{array}{c}1 \text { hora } \\
\text { a } 2 \\
\text { horas } \\
(\%)\end{array}$ & $\begin{array}{c}\text { Mais } \\
\text { de } 2 \\
\text { horas } \\
(\%)\end{array}$ \\
\hline \multirow{5}{*}{ São José } & Serraria & 8 & 59 & 25 & 7 & 1 \\
\hline & Areias e Ipiranga & 8 & 62 & 25 & 3 & 1 \\
\hline & Barreiros & 13 & 61 & 23 & 2 & 1 \\
\hline & Campinas & 11 & 54 & 30 & 5 & - \\
\hline & $\begin{array}{l}\text { Forquilhinhas e } \\
\text { Roçado }\end{array}$ & 10 & 61 & 26 & 3 & - \\
\hline \multirow{4}{*}{ Palhoça } & Ponte Imaruim & 9 & 57 & 27 & 6 & 1 \\
\hline & Pagani & 16 & 60 & 19 & 5 & - \\
\hline & Barra do Aririú & 5 & 46 & 38 & 11 & - \\
\hline & Aririú & 11 & 49 & 30 & 10 & - \\
\hline \multirow{6}{*}{ Florianópolis } & Coqueiros & 8 & 69 & 19 & 4 & - \\
\hline & $\begin{array}{l}\text { Pântano do Sul e } \\
\text { Campeche }\end{array}$ & 9 & 37 & 33 & 20 & 1 \\
\hline & $\begin{array}{l}\text { Lagoa da } \\
\text { Conceição }\end{array}$ & 18 & 43 & 31 & 6 & 2 \\
\hline & Ingleses & 9 & 42 & 25 & 22 & 2 \\
\hline & Canasvieiras & 13 & 49 & 29 & 8 & 1 \\
\hline & $\begin{array}{l}\text { São João do Rio } \\
\text { Vermelho }\end{array}$ & 5 & 33 & 31 & 29 & 2 \\
\hline \multirow{3}{*}{ Biguaçu } & Fundos & 11 & 50 & 31 & 7 & 1 \\
\hline & Vendaval & 7 & 51 & 35 & 6 & 1 \\
\hline & Centro & 5 & 53 & 36 & 6 & - \\
\hline
\end{tabular}

Ademais, a baixa frequência e a redução de frequência nos entrepicos - associada a uma interface de comunicação pouco desenvolvida entre usuário e sistema - faz com que o usuário espere por mais tempo o ônibus, ou tenha que se organizar em função do sistema de transporte. De todos modos, esse cenário limita a acessibilidade à cidade e estimula o uso de veículos individuais privados, que como podemos observar, domina a matriz modal da região (Quadro 4).

Quadro 4. Matriz modal em percentuais de usuários dos modos de transporte urbano na RMF, em 2014. Fonte: Consórcio Logit Strategy (2015).

\begin{tabular}{|l|c|c|c|}
\hline Municípios da RMF & $\begin{array}{c}\text { Mobilidade } \\
\text { não } \\
\text { motorizada }\end{array}$ & $\begin{array}{c}\text { Transporte } \\
\text { individual } \\
\text { motorizado }\end{array}$ & $\begin{array}{c}\text { Transporte } \\
\text { público }\end{array}$ \\
\hline Águas Mornas & 20,2 & 50,3 & 29,5 \\
\hline Angelina & 34,4 & 35,6 & 30,0 \\
\hline Anitápolis & 71,4 & 27,4 & 1,1 \\
\hline Antônio Carlos & 42,5 & 41,6 & 15,8 \\
\hline Biguaçu & 24,3 & 42,9 & 32,8 \\
\hline Florianópolis & 25,8 & 47,7 & 26,4 \\
\hline Palhoça & 24,6 & 46,7 & 28,6 \\
\hline Rancho Queimado & 34,8 & 57,5 & 7,7 \\
\hline $\begin{array}{l}\text { Santo Amaro da } \\
\text { Imperatriz }\end{array}$ & 20,2 & 63,0 & 16,9 \\
\hline $\begin{array}{l}\text { Governador Celso } \\
\text { Ramos }\end{array}$ & 49,0 & 34,0 & 17,0 \\
\hline São Bonifácio & 40,1 & 44,3 & 15,6 \\
\hline São José & 23,6 & 53,1 & 23,4 \\
\hline $\begin{array}{l}\text { São Pedro de } \\
\text { Alcântara }\end{array}$ & 16,0 & 38,3 & 45,7 \\
\hline
\end{tabular}


Na RMF, os usuários de automóveis e motocicletas (individual privado), correspondem entre $34 \%$ e $63 \%$ da população que se desloca, sendo hegemônicos na maioria das cidades da região. Excetuamos as pequenas cidades de Anitápolis, Antônio Carlos e Governador Celso Ramos, nas quais ora o transporte público, ora as mobilidades não-motorizadas, acabam sobressaindo. Isso se explica, em parte, pelo fato de que além de serem municípios de pequeno porte, suas rendas médias estão entre as menores da região.

Esse é o resultado, quando as lógicas de mercado - de eficiência econômica do capital de transportes - se sobrepõem à eficácia social do valor de uso coletivo. Apesar dos efeitos negativos desse modelo de oferta de serviços, que é incapaz de competir com o automóvel, os poucos planejadores institucionalizados da RMF são avessos ao debate sobre a necessidade de subsídios. Para a maioria deles, os sistemas de transporte público têm que se "auto remunerar". Enquanto isso, entre os sistemas de transporte público mais bem-sucedidos da Europa, os subsídios chegam a 55\% dos custos totais (caso de Barcelona). ${ }^{5}$ Além dos subsídios, políticas de densificação mista do uso do solo favorecem, nessas cidades, a eficiência econômica dos transportes públicos, ao mesmo tempo em que estimulam as proximidades urbanas. Entretanto, na RMF, os Índices de Renovação de Passageiros (IR) tem apontado para um espaço pouco misto, na medida em que ao longo de muitas linhas de transporte público, verifica-se pouco sobe-desce (Quadro 5).

Quadro 5. Passageiros embarcados, IPK e Índice de Renovação das empresas operadoras de transporte público da RMF, em 2014. *Quanto mais próximos de 1,00, piores são os Índices de Renovação, denotando embarques volumosos, mas muito concentrados em um único ponto, e desembarques igualmente concentrados em único ponto. Fonte: Consorcio Logit Strategy (2015).

\begin{tabular}{|l|c|c|}
\hline Áreas e trajetos & $\begin{array}{c}\text { Embarque de } \\
\text { passageiros/dia } \\
\text { (médio) }\end{array}$ & $\begin{array}{c}\text { Índice de } \\
\text { Renovação* }\end{array}$ \\
\hline Biguaçu ao Centro de Florianópolis & 2.313 & 1,16 \\
\hline Norte da Ilha ao Centro de Florianópolis & 2.085 & 1,23 \\
\hline São José a Florianópolis & 1.712 & 1,10 \\
\hline Santo Amaro da Imperatriz a Florianópolis & 219 & 1,30 \\
\hline Sul da Ilha ao Centro de Florianópolis & 1.492 & 1,25 \\
\hline Palhoça a Florianópolis & 1.554 & 1,14 \\
\hline $\begin{array}{l}\text { Áreas centrais de Florianópolis e bairros no entorno do } \\
\text { centro }\end{array}$ & 2.916 & 1,49 \\
\hline
\end{tabular}

Em grande medida, esses dados se explicam pelo fato de que não há um histórico de políticas efetivas de densificação e de usos mistos do solo na região, o que exigiria a entrada do Estado no mercado de terras. Pelo contrário, o mercado imobiliário da região é fortemente concentrado em produtos de alto padrão e apenas quando há subsídios estatais, parte dos promotores imobiliários passa a atender também aos segmentos de baixo padrão, mas sob a condição de uma moradia periférica, com baixa acessibilidade aos equipamentos e atividades urbanas e, assim, a necessidade - inclusive de segmentos de baixa renda - de possuírem automóveis ou motocicletas. Tem-se, assim, segmentos sociais de alto status com proximidade aos espaços de consumo, lazer, trabalho e cultura, preferencialmente na Ilha de Santa Catarina (na faixa costeira) e os segmentos sociais de baixa renda habitando espaços monofuncionais mais interiorizados na região, em municípios como Palhoça e Biguaçu (Quadro 6).
5. É importante ressalvar que no Brasil o vale-transporte (VT) vigora como uma forma de subsídio. No entanto, essa subvenção atende apenas aos trabalhadores que possuem vínculo empregatício formal. Em um contexto de recessão como o atual, no qual tem aumentado significativamente o trabalho informal, uma massa de trabalhadores tem sido excluída (Vasconcellos, 2014). Ressaltase que historicamente, o VT se prestou a evitar a falência dos sistemas de transporte público no contexto do subdesenvolvimento, uma vez que ele garante receitas ao sistema. O VT, no entanto, não pôde requalificar a qualidade dos transportes públicos, que é o que aqui expomos como necessidade premente para torna-lo atrativo e propiciar fidelização de usuários. 
Quadro 6. Comparações do percentual de unidades de apartamentos em lançamento, preços e outras características, em Florianópolis, São José, Biguaçu, Palhoça e Governador Celso Ramos, entre 2010 e 2014. Fonte: Consórcio Logit Strategy (2016).

\begin{tabular}{|c|c|c|c|c|c|c|c|c|}
\hline $\begin{array}{l}\text { Municípios } \\
\text { da RMF }\end{array}$ & $\begin{array}{c}\text { Apartamentos } \\
\text { lançados }\end{array}$ & $\begin{array}{l}\text { Apartamentos } \\
\text { disponíveis para } \\
\text { a venda }\end{array}$ & $\begin{array}{l}\text { Vagas de } \\
\text { garagem }\end{array}$ & Grandeza & $\begin{array}{c}\text { Area } \\
\text { construída } \\
\text { por imóvel } \\
(\mathrm{m} 2) \\
\end{array}$ & \begin{tabular}{|c|} 
Preço do \\
metro \\
quadrado (R\$/ \\
$\mathrm{mz})$
\end{tabular} & $\begin{array}{l}\text { Preços dos } \\
\text { Imóveis (R\$̣) }\end{array}$ & Total (\%) \\
\hline Florianópolis & 4.399 & 1.052 & Até 6 & $\begin{array}{l}\text { Min. } \\
\text { Media } \\
\text { Máx. }\end{array}$ & $\begin{array}{r}54 \\
96 \\
283 \\
\end{array}$ & \begin{tabular}{|r|}
3.085 \\
6.681 \\
17.104 \\
\end{tabular} & $\begin{array}{c}171.915 \\
695.218 \\
3786.000 \\
\end{array}$ & 41 \\
\hline São José & 3.817 & 83 & Até 3 & $\begin{array}{l}\text { Min. } \\
\text { Media } \\
\text { Máx. }\end{array}$ & $\begin{array}{c}45 \\
74 \\
325 \\
\end{array}$ & $\begin{array}{l}2.233 \\
3.613 \\
5.957 \\
\end{array}$ & $\begin{array}{c}135.000 \\
275.488 \\
1.119 .316 \\
\end{array}$ & 36 \\
\hline Palhoça & 1.207 & 303 & Até 3 & $\begin{array}{l}\text { Min. } \\
\text { Media } \\
\text { Máx. }\end{array}$ & $\begin{array}{c}48 \\
73 \\
281 \\
\end{array}$ & $\begin{array}{l}2.131 \\
3.726 \\
5.458 \\
\end{array}$ & $\begin{array}{c}119.000 \\
282.381 \\
1.290 .353 \\
\end{array}$ & 11 \\
\hline Biguaçu & 964 & 407 & Até 2 & $\begin{array}{l}\text { Min. } \\
\text { Media } \\
\text { Máx. }\end{array}$ & $\begin{array}{r}48 \\
65 \\
157 \\
\end{array}$ & $\begin{array}{l}1.803 \\
2.796 \\
4.883 \\
\end{array}$ & $\begin{array}{c}99.990 \\
190.194 \\
614.973 \\
\end{array}$ & 9 \\
\hline $\begin{array}{l}\text { Governador } \\
\text { Celso Ramos }\end{array}$ & 328 & 104 & Até 2 & $\begin{array}{l}\text { Min. } \\
\text { Media } \\
\text { Máx. }\end{array}$ & $\begin{array}{c}65 \\
106 \\
220 \\
\end{array}$ & $\begin{array}{l}2.888 \\
4.308 \\
15.550 \\
\end{array}$ & $\begin{array}{c}240.937 \\
446.179 \\
1.555 .000 \\
\end{array}$ & 3 \\
\hline
\end{tabular}

Os novos espaços de moradia de Palhoça - que como podemos observar (Quadro 6), foram 11\% dos imóveis em lançamento (no ano de 2015-2016) pesquisados -, possuem forte característica de atendimento das demandas do Programa Minha Casa Minha Vida (PMCMV), com um preço médio do metro quadrado menor do que aqueles encontrados em Florianópolis e um padrão construtivo mais modesto, com máximo de 3 vagas de garagem e média de 73 metros quadrados.

Quanto aos capitais imobiliários que atuam nestas áreas da RMF, os mesmos tiveram cerca de 1.000 imóveis liberados em apenas um ano, no ponto alto do credito imobiliário da última década, sem quaisquer procedimentos desde o poder público, no sentido de garantir/exigir proximidade com equipamentos coletivos e contrapartidas que seriam importantes ao sistema viário (bastante sinuoso e incompleto) e aos transportes públicos. O fato contundente é que embora o PMCMV tenha trazido a possibilidade de moradia a baixo preço para demandas antes não-solváveis do ponto de vista do capital imobiliário, os edifícios são construídos em espaços periféricos, inclusive nos limites entre o perímetro urbano e o espaço rural. Isso quando não avançam sobre a área rural.

Esse é caso do loteamento Francisco Thiessen, o qual localiza-se nos limites ao sul do município de Palhoça, espaço de característica fortemente rural. Trata-se de um produto imobiliário para o atendimento de 3.000 pessoas, mas em um espaço quase que absolutamente monofuncional. Nesse contexto, os serviços de transporte público oferecem apenas uma frequência mínima, consoante o objetivo de eficiência econômica dos operadores (Quadro 7). 
Quadro 7. Linhas e horários do transporte público nos pontos de ônibus da Rua Nereu Ghizoni, que atendem ao loteamento Francisco Thiessen em Palhoça, em 2018. Fonte: Empresa Jotur (2018).

\begin{tabular}{|c|c|}
\hline Linhas de ônibus & Horários \\
\hline Ticen via Guarda/lvo Silveira & osh e 16 min. \\
\hline Ticen via Ivo Silveira & osh e $30 \mathrm{~min}$. \\
\hline Estação Palhoça via CT/BR-101 & o6h e $01 \mathrm{~min}$. \\
\hline Estação Palhoça via CT/Elza Lucchi & o6h e 31 min. \\
\hline Estação Palhoça via Aniceto Zacchi & oph e $01 \mathrm{~min}$. \\
\hline Aririú Formiga via Aniceto Zacchi & oph e 09 min. \\
\hline $\begin{array}{l}\text { Estação Palhoça via Formiga/Aniceto Zacchi } \\
\text { circular }\end{array}$ & $14 \mathrm{~h} \mathrm{e} 44 \mathrm{~min}$. \\
\hline Guarda via Aniceto Zacchi/Formiga circular & $16 \mathrm{~h}$ e $22 \mathrm{~min}$. \\
\hline $\begin{array}{l}\text { Estação Palhoça via Formiga/Elza Lucchi } \\
\text { circular }\end{array}$ & 17 h e $07 \mathrm{~min}$. \\
\hline Guarda via Aniceto Zacchi/Formiga circular & $18 \mathrm{~h} \mathrm{e} 19 \mathrm{~min}$. \\
\hline $\begin{array}{l}\text { Estação Palhoça via Formiga/Elza Lucchi } \\
\text { circular }\end{array}$ & $18 \mathrm{~h} \mathrm{e} 23 \mathrm{~min}$. \\
\hline Fazenda Jomar via BR 101/Guarda/Formiga & $18 \mathrm{~h}$ e $56 \mathrm{~min}$. \\
\hline Estação Palhoça via Formiga/BR 101 circular & $19 \mathrm{~h} \mathrm{e} 28 \mathrm{~min}$. \\
\hline Guarda via Aniceto Zacchi/Formiga circular & $20 h$ e $19 \mathrm{~min}$. \\
\hline Guarda via Aniceto Zacchi até Aririú Formiga & $22 \mathrm{~h}$ e $34 \mathrm{~min}$. \\
\hline $\begin{array}{l}\text { Estação Palhoça via Elza Lucchi / Saída da } \\
\text { Formiga }\end{array}$ & $22 \mathrm{~h}$ e $45 \mathrm{~min}$. \\
\hline
\end{tabular}

Como é possível analisar (Quadro 7), os operadores não disponibilizam serviço nos horários entrepicos, pois após as 7h e 10 minutos da manhã, o serviço de transporte público só é restabelecido a partir das $14 \mathrm{~h}$ e 44 minutos da tarde. Essa uma característica da oferta de transportes públicos não-subsidiados - e que, portanto, pautam-se apenas na rentabilidade -, a espaços monofuncionais de moradia, ou seja, que não possuem Índices de Renovação de passageiros (IR) adequados. Ora, tal contexto é deletério aos objetivos de mudanças na matriz modal da RMF. Vale ressaltar que dados referentes à expansão da frota de automóveis na região, exibem que entre 2002 e 2017, houve crescimento da frota de automóveis acima, inclusive, de outras regiões metropolitanas brasileiras. Enquanto Porto Alegre registrou expansão da frota de 54\% e Curitiba 79\%, em Florianópolis, a frota de automóveis cresceu 89\%, em São José 154\%, em Biguaçu 237\% e em Palhoça 288\% (Denatran, 2018), o que reflete também um ritmo de desenvolvimento urbano acima da média e, sobretudo, uma topologia desse crescimento urbano que exige o automóvel para a realização das atividades cotidianas.

Assim sendo, uma única tecnologia de transporte público; desintegrada com os demais modos e subsistemas de mobilidade; sob um padrão standard de eficácia e; baseada apenas em eficiência econômica (sem subsídios) é incapaz de reverter o domínio do transporte individual na matriz modal. Tal abordagem apenas reedita paradigmas de planejamento já superados, baseados na mera expansão de sistema viário, com o objetivo de incrementar velocidades ao modo de transporte stricto sensu, ignorando a necessidade de ampliar conectividades ao usuário da tecnologia. ${ }^{6}$ Como veremos a seguir, sem um efetivo fortalecimento institucional - incluindo integrações de trabalho com as secretarias ligadas ao desenvolvimento urbano e regional -, não pode haver integração física eficaz dos sistemas de transporte público e menos ainda, uma efetiva estratégia de desenvolvimento urbano orientado pelo transporte público.
6. Uma das características do já superado paradigma moderno de planejamento de transportes é a preocupação em expandir indefinidamente sistema viário como sendo esta a solução para os congestionamentos (Vasconcellos, 2000). Outra característica, ainda presente no planejamento da mobilidade brasileiro é a unimodalidade, ou seja, a abordagem em transportes na qual uma única tecnologia standard é empregada independentemente das variações territoriais e diferenças nos padrões de mobilidade dos diferentes grupos sociais (Ascher, 2010). Em oposição a estas abordagens, os novos paradigmas, que congregam posições como a da mobilidade sustentável e do chamado Novo Urbanismo, trazem à tona a necessidade de implementação de "economias de variedade" (Ascher, 2010:87) que, portanto, adaptam a qualidade e quantidade do serviço prestado às especificidades de cada demanda. 


\section{Relações interinstitucionais, financiamento e exploração política da mobilidade na RMF}

A questão da integração interinstitucional e da formação de rótulas metropolitanas de planejamento e gestão dos transportes tem sido um dos temas candentes em várias regiões metropolitanas brasileiras. Em alguns casos pela ineficácia dessas instituições, noutros pela sua ausência. Com efeito, ao analisarmos o estado da arte, observamos que a existência de um transporte público integrado e eficaz não depende apenas da presença de técnicos qualificados e tampouco da mera existência de uma autarquia de planejamento.

Muito além disso, exige ações de integração de trabalho interinstitucional; atuações contínuas de concertação com as administrações municipais, estaduais e federais; operação em dados abertos (open data); estabelecimento de redes de benchmarking com planejadores de outras regiões e países, além, é claro, de recursos contínuos. ${ }^{7}$ Vale ressaltar que o interesse em modernizar efetivamente as instituições e, por conseguinte, os sistemas de transporte público, pode estar associado a aspectos históricos, sociais e culturais, de uma elite urbana capitalista-industrial interessada em reproduzir seu capital de modo mais eficiente, integrando o tecido urbano regional (Cocco, 2017).

Destarte, o caráter historicamente pouco industrialista do tecido social e das elites que comandam o território, pode exercer uma influência negativa sobre políticas de integração territorial. O caso da Região Metropolitana de Florianópolis reflete, em certa medida, essas características históricas, uma vez que se trata de uma região administrativa e com pouca presença de capital produtivo industrial se comparada às demais regiões do estado e do país. Embora não seja o único fator, a forte presença histórica de capitais empregadores de mão de obra, suscita a necessidade de ampliação do mercado de trabalho, a qual pode ser efetuada pelo açambarcamento, a partir das cidades principais, de núcleos rurais e urbanos antes isolados. Foi o caso, em certa medida, da Ensanche (Eixample) de Idelfons Cerdá, que passou a integrar os diferentes núcleos urbanos que hoje compõem a cidade de Barcelona (Miralles-Guasch, 2002). Obviamente que em temporalidades e contextos sócio-espaciais muito diversos.

Vale ressaltar que o caráter autárquico e em alguma medida "autossuficiente" dos núcleos rurais/urbanos, perdurou por muito tempo na então aglomeração de Florianópolis (Silva, 1992). Essas características, em um primeiro momento, conduziram à protelação da integração dos transportes, mantendo a desintegração dos serviços até os dias atuais. Destarte, por muito tempo, esse não foi um tema urgente na agenda pública, a qual foi dominada pela questão da ligação entre o continente e a Ilha de Santa Catarina através das pontes. Até os anos de 1940, os barcos eram a opção preferencial de transporte para muitas localidades e até os anos de 1980, subespaços como os Ingleses (Norte da Ilha) sequer possuíam transporte público regular. Não por acaso, as plataformas políticas eram dominadas pelo tema das "novas pontes", em amparo da Ponte Hercílio Luz, já incapaz de dar conta dos fluxos pendulares. Atualmente, utiliza-se como discurso a necessidade de uma "quarta ponte", novamente, sem tocar nas estruturas de poder entorno dos transportes e da terra urbana e preterindo, dessa agenda, os necessários fortalecimentos e integrações institucionais, bem como a implementação de um mix de tecnologias de transporte e inovações no planejamento dos usos do solo. No que se refere aos serviços de transporte público, atualmente tem vigorado a proposta da implementação de um BRT na região, com a abertura de corredores exclusivos em poucos eixos fragmentados.

Não há, portanto, um sistema de transporte público que efetivamente integre física, tarifária e temporalmente toda a RMF, como resultado de uma instituição metropolitana empoderada para tal. O sistema de integração físico-tarifário temporal vigente se limita ao município Florianópolis. No núcleo conurbado, composto basicamente pelos
7. Entrevista concedida por executivo da empresa Transportes Metropolitanos de Barcelona (TMB), em Barcelona, Espanha, no ano de 2014. 
municípios de Governador Celso Ramos, Palhoça, São José, Biguaçu e Florianópolis, essa integração se limita à proximidade física entre as plataformas de embarque-desembarque no Centro de Florianópolis, concentrados no Terminal de Integração Central, mas com pagamento duplicado de passagem caso se queira utilizar o serviço integrado municipal da capital. Ressalta-se que cada serviço de transporte intramunicipal é gerido por sua autoridade municipal de modo isolado.

Além disso, observa-se uma desintegração tanto física, como tarifária e temporal, entre os serviços municipais de transporte do núcleo conurbado e os serviços de transporte intermunicipais das demais cidades da região. O principal efeito negativo dessa fragmentação é a ocorrência de tempos de deslocamento ampliados pelo tempo de espera, pois não há sincronização de horários entre os serviços de transporte; altos tempos de deslocamento a pé entre terminais na área central de Florianópolis e; custos ampliados de deslocamento. Além disso, é também em função desses custos e tempos incorridos dentro do sistema de transporte público - além do desconforto, microacessibilidade inadequada e outras variáveis -, que evolui historicamente, na matriz modal da região, um amplo domínio do uso do automóvel privado em detrimento dos demais modos.

Assim, o caráter desintegrado dos sistemas de transporte público, os altos tempos de deslocamento e o uso exponencial do automóvel, são o resultado territorial da desintegração institucional no planejamento e na gestão regional da mobilidade. Apesar da recente criação da Superintendência do Desenvolvimento Região Metropolitana de Florianópolis (Suderf) em 2014 - a qual deveria funcionar como instituição metropolitana de planejamento -, a autarquia não possui orçamento próprio e tem um quadro de funcionários exíguo. Outra questão fundamental é que a autarquia não foi criada por iniciativa do conjunto das prefeituras, dentro de um entendimento da necessidade de partilhar problemas e soluções na escala metropolitana. Embora uma rótula de planejamento e gestão seja necessária, sua criação foi uma iniciativa verticalizada do Governo do Estado, fato que gerou inquietação entre as prefeituras e órgãos de planejamento do Estado de Santa Catarina.

Além disso, autarquias como o Consorcio Regional de los Transportes de Madrid (CRTM) e a Autoritat del Transport Metropolità (ATM), de Barcelona, já são criadas com poder legal de sobrepor-se às instituições preexistentes, bem como dotadas da capacidade de financiar as intervenções sobre o espaço. No caso de Madri por exemplo, para que houvesse cessão de atribuições de planejamento dos transportes dos municípios para a CRTM, a nova instituição propôs arcar com $50 \%$ dos custos dos transportes públicos dos municípios que aceitassem ceder essas atribuições. ${ }^{8}$ No caso da ATM de Barcelona, uma das principais inovações advém do fato de que ela passa a receber diretamente os recursos provenientes das tarifas pagas - que antes permaneciam nas mãos dos operadores - e devolve esses recursos com a taxa de lucro contratual somada ao subsídio do operador. Ou seja, essas instituições, além de conformarem-se com um quadro técnico considerável, com poder de pressão sobre as demais administrações e amparadas sob uma Lei de Mobilidade Urbana, podem exercer uma persuasão financeira sobre o sistema. ${ }^{9}$

A Suderf surge sem orçamento próprio e busca internalizar atribuições de planejamento dos municípios - como o controle do cálculo tarifário dos transportes públicos - sem lhes oferecer quaisquer contrapartidas. Vale ressaltar que os municípios brasileiros mantem históricas relações clientelistas com os operadores de transporte público. Diversamente aos demais países da América Latina, o Brasil promoveu, entre as décadas de 1960/1970, estímulos para a concentração de capital dos operadores de ônibus (Brasileiro, 1999). Assim, pequenas empresas de ônibus se converteram em grandes grupos empresariais com poder de pressão sobre os fragilizados municípios brasileiros.
8. Entrevista concedida pelo representante da European Metropolitan Transport Authorities na Espanha e diretor de Relações Externas do Consórcio Regional de Transportes de Madri - CRTM, em Madri, Espanha, no ano de 2014.

9. Entrevista concedida pelo Diretor Técnico da Autoridade de Transportes Metropolitanos de Barcelona (ATM) em Barcelona, Espanha, no ano de 2014. 
No caso específico da RMF, a criação da Suderf e da própria Lei que institui a Região Metropolitana de Florianópolis foram demandas do Governador do Estado, aprovadas sem um significativo debate. Há, portanto, um forte componente político por trás dessas ações. Vale ressaltar que os poucos técnicos e planejadores da Suderf têm sido orientados e pressionados a elaborar soluções em transporte público de rápida implementação. O próprio Governador, em reunião fechada ao público no ano de 2015, declarou que o Governo catarinense deve ser o governo da realização, do "fazejamento" e não do planejamento, expressando um demérito à atividade de planejamento. Além disso, o próprio direcionamento dado à autarquia, com poucos técnicos disponíveis, denota o objetivo de implementação de um BRT, pela rapidez e menor custo de implantação; a possibilidade de implantação apenas parcial de alguns elementos sistema; a possibilidade de modificar o sistema de modo conservador, não tocando nas estruturas de poder preexistentes e; a possibilidade de internalização de ganhos eleitorais a curto prazo. Contradições entre as instituições de planejamento, como impasses no que se refere às jurisdições e à atuação de cada uma delas, ocorrem justamente porque o Estado tem se isentado, historicamente, em modificar de modo mais radical essas superestruturas institucionais. Apesar da criação da Suderf como sendo uma autarquia metropolitana para gerenciar e planejar a mobilidade, o Departamento Estadual de Transportes e Terminais (Deter) ainda é a autarquia que, a rigor, incorpora a atribuição de zelar pelo planejamento e pelo funcionamento dos serviços de transporte público intermunicipais e de característica metropolitana. ${ }^{10}$

Outro problema crítico derivado de uma estrutura institucional rígida e fundamentada anteriormente à Constituição é que o Deter se mantém como uma autarquia comum, ou seja, não possui nenhuma autonomia para estabelecer políticas de transporte mais diretivas concebidas desde o staff de planejadores e técnicos. Diversamente das autarquias especiais, todas as iniciativas do Deter têm que passar pela Casa Civil e a Assembleia estaduais, e quando retornam à autarquia, já estão descaracterizadas, com os avanços que haviam sido programados sendo bloqueados pelas estruturas conservadoras internalizadas na esfera política. A própria diretoria da autarquia não é concursada e os diretores nomeados que atuaram de modo mais enérgico no sentido de mudanças institucionais, foram rapidamente apeados do cargo. Assim sendo, a atribuição planejadora da instituição fica comprometida. Por exemplo, no caso das frequências e horários do serviço de transporte público intermunicipal - uma questão crítica de ineficácia - o legislativo aprovou uma legislação que garante às empresas o direito de modificar, reduzir ou cancelar seus horários, com a mera condição de que posteriormente às modificações comuniquem formalmente o Deter. A autarquia, portanto, age atualmente como um órgão meramente "cartorial" para as empresas de transporte, na medida em que estas necessitam de certas documentações para operarem, como certificações, licenças etc.

Desde a fundação da autarquia em 1980, foi aberto apenas um concurso público no ano de 2010, ocasião na qual foram admitidos 36 novos fiscais para o quadro de funcionários, somando, ao todo, 50 fiscais, o que em si é insuficiente para dar conta da frota de 6.000 ônibus de todo o estado. Outra questão é que, em geral, se trata de um funcionalismo antigo, defasado, com pouco estímulo a modificar o sistema. Ressalta-se que o Deter se custeia mediante um sistema de remuneração deletério à instituição, baseado na arrecadação de um percentual da receita dos operadores privados. Os recursos, muito pequenos, são empregados basicamente para custear as despesas administrativas. Não sobram recursos para a construção de uma nova sede, inversões em um terminal de ônibus ou recursos necessários para equipar a autarquia com TICs. Em 2009, sob a justificativa de melhorar o serviço para os usuários, os operadores privados pressionaram o Estado por uma nova política fiscal, que reduziu de $10 \%$ para $5 \%$ os valores direcionados ao Deter, sendo que a receita do sistema não aumentou.
10. Entrevista concedida pelo Arquiteto e Coordenador Técnico da Granfpolis - Associação dos Municípios da Região da Grande Florianópolis, em Florianópolis, no ano de 2015. 
Há, portanto, uma pressão para a autarquia reduzir seu custo para as empresas operadoras, mas isso não se converte em qualidade para os usuários, já que via de regra não há exigências claras de qualidade e eficácia. Na prática, trata-se de um aumento artificial da taxa de lucro das empresas operadoras, a qual, deveria aproximar-se a $12 \%$ (estipulado pelo Estado). Entretanto estima-se que esta esteja acima de $20 \%$. Uma vez que os dados contábeis estão sob controle exclusivo dos operadores privados e o Deter não possui ingerência sobre eles - e, ainda, os dados repassados espontaneamente pelos operadores não são confiáveis - surpreendentemente a Comissão de Política de Transportes do Deter não conhece, com precisão, a taxa de lucro atual praticada pelas empresas. ${ }^{11}$

Os técnicos do Deter somente conseguem ter acesso a esses dados mediante auditorias externas, o que não possibilita antever o comportamento do sistema, propiciando um planejamento mais preditivo. No caso da Suderf - a nova autarquia que objetiva substituir o Deter no planejamento e gestão dos serviços de característica metropolitana ocorre o mesmo, já que os recursos provenientes das tarifas dos serviços municipais não são geridos pela autarquia, mas concentrados no Sindicato das Empresas de Transporte Urbano de Florianópolis (Setuf) e redistribuídos aos próprios operadores. Portanto, a atribuição de centralização contábil de um sistema integrado, presentes na ATM de Barcelona e na CRTM de Madri, não existe no caso catarinense.

É importante salientar que não se trata de efetuar uma comparação vis a vis entre esses casos. O fato é que há similaridades de trajetória entre os casos brasileiros - em especial na Grande Florianópolis - e os casos catalães e madrilenos. Em Barcelona por exemplo, a criação da ATM por parte da estrutura política catalã não se deu em função de obrigação legal, mas devido a uma exigência por parte do Estado espanhol para que este concedesse subsídios e recursos ao sistema catalão, então em colapso financeiro. ${ }^{12}$ Tratou-se de uma inovação institucional. A lei de mobilidade catalã é promulgada depois, como superestrutura que contribui para sedimentar e aprofundar os avanços obtidos. É justamente por essas características que a trajetória institucional catalã serve de pedra-de-toque ao caso brasileiro e catarinense.

A origem e trajetória das instituições de planejamento de transportes públicos da Grande Florianópolis é diversa, pois a noção da necessidade de subsídio para garantir qualidade ao sistema não se sedimentou entre os planejadores, no decorrer da história da Região. Além disso, autarquias como o Deter (Departamento de Transportes e Terminais), criadas no final do período militar (em 1980, em um contexto de bancarrota do Estado brasileiro), se custeiam mediante a arrecadação de um percentual de receita dos operadores privados de ônibus, um modelo deletério ao planejamento, já que a tendência é que o capital pressione o Estado a reduzir suas despesas. Já a Suderf (Superintendência de Desenvolvimento da Região Metropolitana de Florianópolis), é criada em 2014, pouco antes da Lei Federal do Estatuto das Metrópoles (2015) e posteriormente à Lei Federal de Mobilidade Urbana (2012). Além disso, vale ressaltar que Barcelona e Madri mantiveram e aperfeiçoaram suas empresas públicas de transporte, abrindo espaço para um sistema misto, com operadores públicos e também privados. Destarte, uma das conclusões que se pode obter, a partir das análises conjuntas dessas trajetórias é a do caráter geral da importância de uma formação crítica do planejador, da necessidade de implementação de subsídios e do financiamento público contínuo às instituições de planejamento e gestão, a partir de fontes mais perenes. Assim, a centralidade do fator político-econômico como ponto de ignição de inovações institucionais sobrepuja a centralidade do próprio quadro normativo.
11. Entrevista concedida pelo fiscal e integrante da Comissão de Política de Transportes do Departamento de Transportes e Terminais de Santa Catarina, Deter-SC, em Florianópolis, no ano de 2015.

12. Entrevista concedida pelo Diretor Técnico da Autoridade de Transportes Metropolitanos de Barcelona (ATM) em Barcelona, Espanha, no ano de 2014. 


\section{Lógicas conservadoras e lógicas neoliberais no planejamento dos transportes e da mobilidade urbana na RMF}

Apesar da importância dos chamados novos paradigmas em planejamento urbano, há que ressaltar que a concretização dessas abordagens pressupõe um empoderamento do Estado e de suas instituições, preenchidos por um novo conteúdo social (Mackinnon, Shaw \& Docherty, 2010). Ou seja, novos quadros técnicos, políticos e de gestão, compostos por intelectuais orgânicos às necessidades da população e que, em face ao avanço neoliberal, componham uma frente de defesa dessas instituições contra os desmontes que têm sido perpetrados. Autores como Paget-Seekins (2015), Farmer (2011) e Figueroa (2007) tem expressado - cada qual a seu modo - preocupação com a forma com a qual o neoliberalismo tem atingido os transportes públicos e a mobilidade, setores vitais à expansão das interações espaciais e, por conseguinte, à ampliação das capacidades produtivas humanas (Silveira \& Cocco, 2013). Portanto, o encaminhamento da questão social em termos de transportes e mobilidade passa, necessariamente, por um projeto de poder, justamente para que o campo popular possa assumir o Estado e suas instituições.

No caso brasileiro e catarinense, lógicas neoliberais passam a atuar dentro das instituições de planejamento, combinadas à praxis conservadora que permanece e que reedita modelos já ultrapassados de planejamento. Essas ações, ao manter o status quo a partir de intervenções muito superficiais sobre os sistemas de transporte, não tocam nos interesses das estruturas conservadoras de poder da região. A questão da defasagem do pessoal técnico-executivo de planejamento e ao mesmo tempo, a terceirização de processos-chave de planejamento são essenciais para entender essa fragilização institucional. No caso da RMF, essa defasagem, tanto em termos quantitativos quanto qualitativos, tem levado ao fortalecimento de intencionalidades e visões de mundo da iniciativa privada para dentro da esfera pública, além de inconsistências nas análises territoriais.

O sucateamento da atividade de planejamento a partir da redução de concursos públicos e o emprego da iniciativa privada (terceirização) em atividades core da área de planejamento são elementos essenciais desse debate. Contudo, não se trata apenas de capacidade técnica, pois estes quadros devem ter também uma visão política avançada no sentido do empoderamento popular, na promoção e aperfeiçoamento contínuo dos planejamentos participativos e na criação de mecanismos de democracia direta. A própria noção de "mobilidade sustentável" não se mantém sem a consciência da população em geral, com relação a seus objetivos primaciais (Lindenau \& Böhler-Baedeker, 2014). Noutros termos, trata-se da ação do técnico-planejador público como intelectual orgânico das massas às quais deve diligência (Gramsci, 1968).

No entanto, os próprios estudos e proposições tem sido delegados à iniciativa privada de modo inadequado e deixados à fruição do mercado. No ano de 2014, em meio à aprovação do projeto de Lei da Região Metropolitana e da Suderf, a autarquia pública Santa Catarina Parcerias e Participações (SCPar), torna público um Procedimento de Manifestação de Interesse (PMI), o qual consistiu na chamada pública para que assessorias privadas elaborassem estudos sobre sistemas de transporte público que seriam os mais adequados para a RMF. Vale ressaltar que as PMIs, quando concebidas de modo estratégico por uma autarquia pública forte, são orientadas, ou seja, os estudos prévios e os objetivos que determinam a escolha desta ou daquela alternativa tecnológica de sistema de transporte (ou de um conjunto de tecnologias), se origina no poder concedente.

No caso da PMI realizada em Florianópolis, a fragilidade das instituições públicas ficou evidente. Na medida em que o procedimento foi realizado, sem um objetivo prévio 
desde o Estado, o mesmo redundou em incertezas sobre o que, exatamente, o Estado objetivava com a PMI. Na esteira dessa indefinição surgiram propostas muito desconexas com a complexidade do espaço regional da RMF. A proposta vencedora - do grupo malaio Scomi - baseava-se na construção de um monotrilho elevado, entre os eixos troncais continente-ilha, prevendo a construção de grandes bolsões de estacionamento associados a restrições de passagem, conduzindo artificialmente a demanda para dentro do sistema, tornando-o, assim, rentável para o capital investidor. Esse é outro problema que deve ser considerado. Quando não há perspectivas de aporte de subsídios, a modelagem financeira que garante uma determinada Taxa Interna de Retorno (TIR) ao investidor é a que baliza e modula o próprio projeto. A PMI realizada em Florianópolis em 2014 foi um exemplo de como os interesses privados podem se sobrepor ao público, devido à ausência de uma instituição capacitada a conduzir todo o processo como rótula de planejamento (Miralles \& Cebollada, 2003). Inclusive, em determinados momentos, as empresas envolvidas na PMI tratavam diretamente com as prefeituras, buscando auferir vantagens devido à conhecida fragilidade das mesmas. 13

Posteriormente às PMIs, quem tem tomado a frente dessas iniciativas, no caso da RMF, são assessorias privadas em cujo portfólio de serviços está a implantação de BRTs. Vale ressaltar que não se trata de negligenciar a expertise da iniciativa privada. A assessoria privada que venceu a chamada pública para a realização do estudo Plamus, por exemplo, possui ampla expertise em estudos de origem-destino e estudos de prospecção em transportes e mobilidade em todo o mundo, o que poderia agregar conhecimento ao próprio Estado. No entanto, na medida em que há o interesse direto da empresa na implantação de BRTs, o relatório por ela produzido tendeu a avaliar mais positivamente o emprego de sistemas BRT do que outras tecnologias.

No relatório, os agentes privados expõem, entre outras vantagens, que o BRT possibilita a implantação de serviços expressos (linhas diretas sem integração forçada), enquanto, supostamente, essas aplicações seriam inviáveis no caso dos VLTs. Entretanto, foi justamente através dos serviços expressos e da operação segregada na maior parte dos trajetos, que se reduziram em até 6 minutos os trajetos interurbanos dos VLTs na Área Metropolitana de Madri, garantindo velocidades comerciais acima de $20 \mathrm{~km} / \mathrm{h}$. Ainda em defesa do BRT para a RMF, esses agentes expõem o caso de Bogotá - onde o sistema Transmilenio ultrapassou os 40.000 passageiro/hora/sentido - como "uma quebra de paradigma de capacidade dos sistemas BRT" e assim, uma prova de superioridade do sistema. Deve-se perguntar, entretanto, em que condições de conforto se realizam essas mobilidades. Ademais, grande parte dos planejadores e estudiosos do caso de Bogotá tem colocado que o Transmilenio ultrapassou sua capacidade de servir adequadamente ao usuário. Vale sublinhar que o sistema BRT, se comparado aos VLTs, tem menor tempo de implantação, menores custos envolvidos e maior possibilidade de resgate dos investimentos a curto prazo (Paget-Seekins, 2015). Ou seja, se adequa melhor a uma TIR com horizonte de curto/médio prazo, o que não significa que, do ponto de vista das necessidades dos usuários e de um território singular, seja o sistema mais eficaz.

Além das questões econômicas, do ponto de vista da internalização de prestígio político, o BRT é ideal, já que pode ser implantado apenas parcialmente e, ainda sim, ser explorado politicamente, sendo falseado como planejamento de vanguarda (Paget-Seekins, 2015; Figueroa \& Orellana, 2007). Destarte, colocam-se em marcha projetos de transporte sem tornar público que a eficácia social desses sistemas depende de políticas mais amplas de uso do solo; de combinação com outras tecnologias e; alterações profundas nas infraestruturas e meios de transporte, isto é, de estratégias TOD (Cervero \& Dai, 2014). Ademais, as equipes multidisciplinares são imprescindíveis, já que uma das características do BRT é que poucos agentes - tanto públicos quanto privados - conhecem, em sua integridade, os fatores de produção, processos e etapas
13. Entrevista concedida pelo ex-Prefeito de Curitiba-PR e Presidente da Superintendência da Região Metropolitana de Florianópolis - Suderf, em Florianópolis, no ano de 2014. 
necessárias para uma implantação completa e eficaz deste tipo de sistema de transporte público (Lindau, Hidalgo \& Lobo, 2014). Vale ressaltar que o BRT deve ser adaptado a um território concreto, dotado de especificidades que apenas os agentes públicos locais e a própria população estão familiarizados.

A ausência de equipes multidisciplinares nas autarquias e instituições públicas da RMF é um dos elementos explicativos de equivocadas proposições que objetivam apenas plasmar, no território, modelos standard de planejamento de transportes. Não raro, o BRT de Curitiba e de Bogotá são tomados como exemplos a serem seguidos. No entanto, é quimérico pensar em reproduzir as especificidades desses subespaços, bem como o momento histórico no qual esses sistemas foram implantados nesses respectivos lugares. A própria noção de trinário, aplicada com sucesso no BRT de Curitiba, é impraticável em um território como o do litoral de Santa Catarina, recortado por morros, lagos, mangues, restingas e dunas, como salientamos anteriormente. O sistema trinário de Curitiba consiste na hierarquização de 3 vias paralelas, sendo a via central elegida como a troncal, na qual há exclusividade de operação dos ônibus articulados e bi-articulados do sistema BRT, enquanto às vias laterais se transfere o fluxo de automóveis de maior velocidade. Essa organização possibilita segurança e maior microacessibilidade aos usuários do sistema BRT às estações de embarque, localizadas nos canteiros centrais das vias.

Além disso, naquele momento, foram criadas todas as condições - em diferentes escalas e setores que se intersectam à mobilidade - para a eficiência econômica do BRT: 1) uma política de desenvolvimento regional que instituiu a Cidade Industrial na Região Metropolitana de Curitiba; 2) uma política de aquisição de terras por parte do poder público, em espaços centrais ao longo do eixo troncal de transporte público e; 3) uma política de subsídios sustentada, em parte, pela conjuntura internacional e pela decisão política estadual de renunciar a uma parte do ICMS do óleo diesel (Brasileiro, 1999). Vale ressaltar que os projetos BRT implementados no Brasil naquele período foram resultado, em grande medida, de financiamento internacional. O BID (Banco Interamericano de Desenvolvimento) e Banco Mundial dispõe de canais de financiamento facilitados para sistemas de transporte público rodoviário, mas raramente o fazem para o financiamento de compras de lotes centrais visando usos de solo mistos, sistemas de transporte urbano ferroviários e modos marítimos (Lindau et al, 2014). Atuam, portanto, muito mais na implementação de TAD (Transit Adjacent Development) do que efetivamente na realização de estratégias TOD (Cervero, 2007). Assim, a tomada de decisões acerca das políticas de mobilidade acaba sendo determinada pela combinação dos interesses dos agentes privados de transporte, que no Brasil são parte da estrutura conservadora de poder político, mas também pela disposição ou ausência de sistemas de financiamento. ${ }^{14}$

Ademais, o Relatório Plamus apresenta afirmações questionáveis, como por exemplo a valoração negativa do fato de que a velocidade do VLT varia conforme o entorno e o seu nível de segregação. Concretamente, essa é umas das vantagens do VLT, na medida em que o sistema pode se capilarizar, adentrando áreas centrais, centros históricos e demais espaços nos quais há restrição do ambiente construído, sem, no entanto, gerar impactos negativos. Essa característica possibilita ao passageiro uma microacessibilidade e uma macroacessibilidade que não pode ser obtida com o ônibus. Os novos VLTs são concebidos com piso baixo (low entry), proporcionando microacessibilidade ao nível da rua e, além disso, podem atravessar espaços como praças e centros históricos sem impingir impactos sócio-ambientais negativos. O moderno VLT é elétrico, dispensa catenárias, é silencioso e os trilhos são ao nível do passeio, não gerando barreiras espaciais. Assim, oferece acessibilidade ampliada a espaços que concentram atividades urbanas. Além disso, tomar a velocidade operacional como pedra-de-toque significa retroceder a paradigmas já ultrapassados (Banister, 2008). São a conectividade e a confiabilidade as qualidades fundamentais que devem ser valoradas nos novos sistemas de transporte público.
14. Caberá verificar se as novas fontes de financiamento internacional, como o New Development Bank (NDB) - estruturado no âmbito dos BRICS - e o próprio Asian Infrastructure Investment Bank (AIIB), promoverão a inovação em transportes e mobilidade, facilitando o acesso a crédito para um leque de ações mais diversificadas. 
Assim, as limitações da iniciativa privada que planeja mobilidade residem essencialmente em sua própria natureza ancorada no business: as assessorias privadas de planejamento de transportes, diante de uma lógica de redução de custos, tendem a reduzir esforços no que se refere a estudos mais profundos sobre o território, necessários para a implementação de políticas de transportes e mobilidade efetivas. Assim, quando se abre demasiado espaço para sua atuação - como tem ocorrido em Florianópolis - essas empresas tendem a modular seus diagnósticos e propostas segundo seus interesses imediatos de lucratividade. Os próprios executivos do Sindicato das Empresas Operadoras de Transporte Público Urbano da RMF (SETUF) haviam declarado a "inviabilidade financeira" de os próprios operadores arcarem com uma Pesquisa de Origem-Destino completa.

Finalmente, na medida em que as reuniões de apresentação do estudo à comunidade ocorriam, se tornava cada vez mais clara a fragilidade das instituições públicas, as quais acabavam por assumir os posicionamentos da iniciativa privada, isto é, do grupo privado incumbido da realização dos estudos. Agentes ligados diretamente ao Consórcio privado executor do estudo Plamus na RMF, afirmaram em reunião junto à população, que "a escolha pelo modo/modal de transporte, quem decidirá é a sociedade" e ainda, "que o BRT foi a solução encontrada pelos países pobres para dar conta da mobilidade nas cidades e nós (brasileiros, catarinenses), somos pobres". Essas abordagens, feitas por técnicos que estão no centro do processo de planejamento - na elaboração das matrizes de dados provenientes do território - torna mais do que evidente a fragilidade da organicidade de nossos intelectuais-planejadores, com relação às necessidades da população.

O caso da RMF ilustra como a fragilidade do Estado dá guarida à ampliação das ações dos agentes ligados ao mercado, que inclusive passam a defender publicamente - e em reuniões de participação social - seus portfólios de produtos. Enquanto isso, a população, sem um intelectual capaz de orientá-la em meio à complexidade do debate sobre tecnologia de transportes, acaba por ser persuadida numa ou noutra direção. Isso torna evidente que o fortalecimento das autarquias de planejamento dos transportes e mobilidade devem objetivar não apenas à qualificação técnica de suas atuações, mas a consolidação de um bloco político de interesses pró-mobilidade.

\section{Proposições recentes e modernizações conservadoras nos transportes e na mobilidade na RMF}

No que se refere aos objetos técnicos espaciais que têm sido construídos sob a égide dos enquadramentos institucionais que foram analisados, observam-se algumas características sintomáticas das lógicas que os produziram. Dentre essas, destacamos o tempo demasiadamente curto de maturação dos projetos; o caráter pontual dessas obras no território, com pouca articulação entre si; a superficialidade das intervenções, pois não tocam na estrutura urbana, nos padrões de origem-destino e na matriz modal de deslocamentos; o fato de que não incluem uma reestruturação institucional, como observamos anteriormente, o que fragiliza ações inovadoras advindas de um corpo técnico engajado e; o caráter de ações meramente tangíveis, pois não tocam na estrutura de poder edificada historicamente entorno do capital imobiliário e dos capitais de transportes. Em função dessa quinta característica, esses projetos não podem, portanto, ultrapassar os limites impostos por esses agentes hegemônicos.

No tocante às infraestruturas de transporte, não há um plano que integre a região metropolitana. Essa desintegração resulta de pouca integração de trabalho entre as autarquias, departamentos e secretarias cuja atribuição é o planejamento das infraestruturas de 
transporte. Observam-se, nesse caso, acomodações de interesses e conjuntos de obras justapostas, o que não significa que haja sinergia para a eficácia do conjunto das mesmas. Por exemplo, paralelamente aos objetivos programáticos explicitados por agentes da Suderf - que tem sinalizado para a necessidade de adequações não apenas nos serviços de transporte, mas também no sistema viário metropolitano -, os governos municipais de Florianópolis têm lançado suas próprias propostas. Foi o caso do Sistema Integrado de Mobilidade (SIM), que consistiu em um conjunto de obras de infraestrutura muito pontuais, somadas a algumas readequações conservadoras do serviço de transporte público, a partir de 2014. Observa-se que em diversos momentos a concepção dessas obras entra em contradição com a abordagem que os planejadores da nova autarquia de planejamento - a Suderf - têm com relação à RMF. Assim sendo, há incongruências entre as concepções de planejamento das autarquias do próprio Estado de Santa Catarina e destas com relação às ações da Prefeitura de Florianópolis e de outros municípios. Notadamente, porque as ações ligadas à expansão de infraestrutura viária, levadas a cabo por autarquias e secretarias estaduais de origem antiga - e que sofreram poucas mudanças ao longo do tempo -, tendem a reproduzir um espaço conservador.

Vale ressaltar que a maioria das obras de maior impacto estão sob jurisdição do Departamento Estadual de Infraestrutura (Deinfra), do Departamento Nacional de Infraestrutura de Transporte (Dnit), sob concessão federal (Rodovia BR-101 e a Alça de Contorno) ou são iniciativas do Consórcio Fênix - o consórcio das empresas operadoras privadas de transporte público de Florianópolis -, que colabora, na verdade, com o aumento de sua própria eficiência econômica, como é o caso da implantação dos GPS nos ônibus e da implantação de um novo sistema de gestão de tráfego. Esses são alguns elementos importantes da discussão, que para além da superestrutura institucional, referem-se à superestrutura política, pois o eleitorado brasileiro tem se mostrado bastante sensível ao tema mobilidade e transportes nas cidades, cujos problemas afetam distintos segmentos sociais. Diferentes grupos políticos buscam, assim, capitalizar-se politicamente a partir desse tema, mesmo que para isso apenas emulem mudanças profundas nos transportes, mas que, na realidade, tratam-se de modificações apenas superficiais.

A omissão com relação à necessidade de um ordenamento real, concreto, da dinâmica metropolitana - baseado em planejamento público - reduzindo tempos de deslocamento e melhorando as condições de mobilidade é confirmada pela forma como tem ocorrido algumas obras na Ilha de Santa Catarina. Por exemplo, equipamentos que se tornarão centralidades importantes, como os Condomínios Empresariais Sapiens Park e SC Square, estabelecidos ao longo da rodovia SC-401, tem uma integração com o transporte público praticamente nula. Por outro lado, um corpo consolidado de técnicos-planejadores de carreira, com a possibilidade de benchmarking constante com diferentes instituições metropolitanas, incomodaria os agentes e grupos que se beneficiam deste status quo, pois tocaria no substrato econômico destas estruturas políticas.

No caso da Rodovia BR-101 e da Alça de Contorno, que visam dar mais capacidade viária ao fluxo de passagem de longa distância - dando maior vazão ao fluxo local/ regional - há também uma série de problemas. Essa questão passa também pela estrutura das origens e destinos, como por exemplo, de moradores do Bairro Serraria, com destino ao bairro Bela Vista, em São José. Estes necessariamente têm que utilizar a rodovia BR-101 somando-se aos fluxos regionais de longa distância, pois as servidões não formam uma malha ortogonal capaz de oferecer alternativas de deslocamento. Além disso, identificam-se algumas questões que vem tornando moroso o processo de mitigação destes problemas, dentre as quais, dificuldades nas relações entre o Estado e o Grupo Abertis (antiga OHL), atual concessionário da rodovia.

Trata-se de uma questão problemática, pois se trata de uma rodovia concessionada, cujos fluxos, sobretudo nos trechos que perpassam os territórios de Biguaçu e São 
José são evidentemente metropolitanos. Para convertê-la em uma verdadeira avenida urbana, operá-la e dotá-la de equipamentos específicos, como redutores de velocidade, sistemas semafóricos, corredores de ônibus e terminais - como expressaram alguns técnicos da Suderf - a concessionária teria que abrir mão da concessão ou dar anuência a estas intervenções. Outro problema é o da lentidão na tomada de decisões e na execução das obras do contorno viário, sem o qual não há como intervir na rodovia adaptando-a ao fluxo pendular metropolitano. A questão é que a concessionária se esquivou de iniciar prontamente as obras do contorno viário da BR-101, declarando, na ocasião, que a obra só resolveria o trafego de passagem e que o trafego local continuaria problemático. Segundo a operadora, drenaria apenas 10\% dos fluxos, além dos impactos ambientais que incorreriam à obra.

Outros estudos, no entanto, expuseram que a drenagem seria de 30\% dos fluxos, mas há discussões de parte a parte no tocante a estas projeções. No imo destes impasses estão os interesses da companhia e a pusilanimidade do Estado. Vale ressaltar que a SPE (Sociedade de Proposta Específica) criada pela então OHL para gerir a rodovia, teria baixa geração de caixa para executar a obra da Alça de Contorno na ocasião, devido à baixa tarifa sugerida inicialmente e que venceu a licitação. Quando se efetuou a concessão à $\mathrm{OHL}$, o grupo criou uma Sociedade de Proposta Específica (SPE) para gerir a concessão, que é independente da empresa mãe (embora a OHL seja a proprietária e tenha as responsabilidades). A OHL, não obstante, deveria dar fé do cumprimento do contrato, por parte de sua SPE. No entanto, na medida em que a taxa de retorno (TIR) não se mostrava satisfatória, os acionistas deixaram de investir na SPE, a despeito do grupo ter ou não capital em caixa.

Esta é uma deformação decorrente da forma de contratação por parte do Estado, quando este efetua concessões baseadas apenas no baixo custo da tarifa sugerida pelo operador e segundo estudos superficiais. Ora, uma concessão desta importância, ocorrida nestas circunstâncias, necessariamente deveria submeter o vencedor a processos profundos de due diligence (auditoria contábil para comprovação de capacidade de inversão). Uma situação semelhante ocorreu com a "linha 4 - amarela" do metrô de São Paulo, onde o consórcio espanhol Isolux Corsán-Corvian aumentou o prazo para o termino das estações Vila Sônia, São Paulo-Morumbi, Oscar Freire e Higienópolis-Morumbi, em 50\%. O Estado rompeu o contrato e voltou a licitar. Não há, portanto, um todo harmônico nas relações interinstitucionais entre Estado e iniciativa privada, entre as próprias autarquias estatais e entre entes federativos, tal como se esforça por demonstrar - com auxílio da grande mídia - as administrações estaduais e municipais. Nem tampouco, essa forma de produzir os objetos técnicos que compõem o espaço é harmônica com as necessidades da população. Pelo contrário, a fragilidade do Estado é patente e apenas reforça a tese da entrada progressiva de lógicas neoliberais para dentro das instituições de planejamento dos transportes e mobilidade. No nível da produção da consciência social, o objetivo é justamente fazer sedimentar, com auxílio da mídia regional, que tal e como está sendo produzido o espaço, trata-se, sim, de interesse da coletividade.

Na RMF é comum, durante a chegada da temporada de férias, os jornais estamparem diuturnamente a "preocupação com a chegada da alta temporada turística" e assim, de "imprimir maior fluidez às rodovias estaduais da Ilha", buscando justificar a execução de obras que apenas consistem na ampliação de sistema viário, sem quaisquer rebatimentos positivos para uma mudança efetiva na matriz de deslocamentos da região. Até porque, muitas dessas obras consistem em ampliações de sistemas rodoviários, que na RMF, operam como vias de ligação metropolitanas. O fato contundente é que na visão das autarquias estaduais e federais que operam essas vias, não há razões para dotá-las de corredores de ônibus, ciclovias e calçadas.

Essas novas obras cristalizam espacialmente, o conservadorismo presente dentro das instituições. Por exemplo, ao invés de se criarem verdadeiras ciclovias e ciclofaixas 
avançando sobre as faixas de rolamento dos automóveis, tem se optado por avançar as ciclofaixas sobre as calçadas, afetando ao pedestre e oferecendo uma infraestrutura de má qualidade ao ciclista. Na realidade, se trata de parte da calçada que é subtraída do pedestre, que recebe uma coloração vermelha, emulando, de modo conservador, a presença de uma ciclofaixa. Vale ressaltar que o convívio entre transporte público por ônibus, automóveis, pedestres e ciclistas é bastante conflituoso no espaço da RMF, o qual é consubstanciado em atropelamentos de ciclistas por ônibus e por automobilistas devido à falta de ciclovias. Também ocorrem situações que exibem o despreparo da superestrutura funcional dos transportes, com relação ao pensamento de vanguarda sobre os transportes. Em Florianópolis é recorrente que ciclistas que tentam entrar em um ônibus com sua bicicleta, sejam constrangidos pela tripulação a descer do ônibus. Além disso, a integração das infraestruturas para o transporte público e para as bicicletas deve ser acompanhada de bicicletários e de um serviço de bicicleta pública capaz de estimular o uso das mesmas e assim, o uso da própria infraestrutura. Como destacamos ao longo deste texto, a ação do Estado é elementar para a implementação de tecnologias e de sistemas inovadores de transportes, fato que exige, por seu turno, políticas inovadoras de outra ordem, isto é, que garantam os recursos necessários à produção e operação adequadas destes objetos técnicos espaciais.

Dos usuários de bicicletas na RMF, 31,1\% não tem renda própria e 25\% tem renda familiar de 1 a 2 salários mínimos. Mas ao contrário do que propala o senso comum sobre o problema, na RMF, $52 \%$ dos deslocamentos efetuados por bicicletas são para o trabalho e 38\% são para a escola (Logit Strategy, 2015), apesar da insuficiência da infraestrutura, dos perigos de trafegar em tráfego misto e do conservadorismo das políticas públicas para os modos não-motorizados. É preciso trazer o segmento social médio na RMF para a prática de deslocamentos não-motorizados, para que esta política se consolide efetivamente e foi o que ocorreu no caso de Barcelona. Isso, no entanto, dependeu de uma forte ação institucional, da criação de uma empresa pública para o planejamento e a gestão do novo sistema de bicicletas públicas, e do entendimento da natureza deficitária desses valores de uso coletivos. Ou seja, investimentos públicos diretos são essenciais para colmatar uma cultura de uso de novas tecnologias, assim como o retorno a formas não-motorizadas de transporte, que em contextos de proximidade urbana são as mais eficazes. Entretanto, os planejadores catarinenses seguem realizando o planejamento tradicional de transportes.

Esse foi o caso da recente duplicação da rodovia estadual SC-401 e SC-403, que conecta os espaços ao norte da Ilha de Santa Catarina e assim, bairros populosos como Ingleses, Rio Vermelho e Canasvieiras aos espaços mais centrais. Trata-se de um exemplo notório da ausência de concertação e de desarcordos no estabelecimento de parâmetros para ações efetivamente metropolitanas. Inicialmente, os integrantes do Departamento de Infraestruturas de Santa Catarina (Deinfra) ignoraram as rodadas de concertação realizadas com agentes da Suderf, cujos técnicos expressaram a necessidade de se começar a tratar alguns eixos de transporte, principalmente no espaço conurbado, como avenidas urbanas e não mais como sendo rodovias. Primeiramente, por que as áreas ao norte, ao sul e a leste da Ilha de Santa Catarina já não são, há muito tempo, meras áreas de balneário. Vale ressaltar que o objetivo inicial das rodovias estaduais era conferir acesso a estas áreas para o lazer, abordagem que parece ter permanecido dentro das instituições (Sugai, 2002). Com relação à rodovia SC-401, apesar dos diálogos interinstitucionais, prevaleceram interesses obscuros e persistência de uma visão baseada na continuação do sistema como sendo o de uma rodovia, ou via expressa.

Destaca-se que a via não apenas foi duplicada em 6 faixas de rolamento, como sofreu alterações para evitar os cruzamentos em nível, com a construção de 3 viadutos, dentro de uma concepção de projeto pautado em possibilitar altas velocidades. Desse modo, mantem-se a concepção de um espaço meramente conectivo, ignorando os bairros populosos 
do entorno e a possibilidade de conversão para uma dinâmica de cidade. Além do conservadorismo em termos de concepção, a obra criou uma ampla barreira geográfica artificial aos espaços urbanizados a ela adjacentes, com acessos para pedestres no segundo plano da infraestrutura, que inibem interações espaciais. Com o mesmo intuito, estão programadas construções de passarelas aéreas para pedestre. Ressalta-se que esta área possui alta frequentação de estudantes devido à presença de escolas, quadras de esportes e comércios, mas com as obras em infraestrutura elevada, os moradores são obrigados a utilizar um perigoso túnel para passagem de pedestres. Apesar dessas incongruências com relação às necessidades concretas da população, a resposta dos técnicos do Deinfra foi a de que apenas "cumpriam ordens" para realizar as obras desta forma.

A concepção da Suderf para esses espaços ao norte da Ilha - mais arrojada e congruente à proposta de um Novo Urbanismo -, era a de uma política de densificação das áreas adjacentes às rodovias SC-401 e SC-403 a partir de usos mistos, com atividades ambientalmente pouco impactantes e moradias, respeitando as limitações da Ilha e criando um bem organizado corredor de ônibus segregado do tráfego, na linha central da faixa de rolamento da via, dispensando a criação de elevados ou passarelas de pedestres. A criação dessa dinâmica, inclusive, contrastaria a eficácia do sistema de transporte público com o tráfego de automóveis, estimulando a transferência modal de usuários de automóveis aos BRTs, VLTs ou VLPs. Esses dois últimos, entendemos que seriam mais eficazes na atração de automobilistas, sejam eles moradores, trabalhadores dos subcentros, ou turistas que visitam a Ilha durante as altas temporadas.

A impossibilidade de abertura de trinários, tal como se fez em Curitiba - aonde o sistema viário em quadriculas era preexistente, possibilitando diferentes modos de organizar o tráfego - seria compensada com reduções de velocidade para o automóvel nas faixas de rolamento laterais ao sistema de transporte público, o que seria salutar para a redução de acidentes. Também poderia ser executada uma sincronização semafórica com "ondas de verde", favorecendo a velocidade comercial do transporte público e amplas faixas de pedestre, para acesso às estações de embarque. A ampliação da via tal como foi executada, dificulta sobremaneira intervenções futuras em microacessibilidade para transportes públicos, bem como desincentiva a realização de usos mistos nas suas adjacências, ao dificultar a mobilidade a pé nos espaços laterais e o cruzamento da via por pedestres, devido à barreira gerada pela nova organização da rodovia. Observa-se que além da alta velocidade, blocos balizadores de concreto de aproximadamente um metro e trinta centímetros de altura foram alinhados no canteiro central, gerando dificuldades físicas para os moradores dos bairros adjacentes atravessarem a via.

No caso da Via Expressa, o projeto do Departamento Nacional de Infraestrutura (Dnit) também contrasta com a abordagem da Suderf. Na concepção da Suderf, seriam criadas duas faixas de rolamento nas laterais, com o BRT no canteiro central. Também seriam corrigidos acessos e ciclovias, enquanto calçadas seriam construídas nas laterais da via. Entretanto, para o pessoal técnico do Dnit, com uma visão voltada à fluidez do automóvel, haveria necessidade de abertura de três faixas de rolamento, uma via para BRT, acostamento, ciclovias e calçadas. Considerando que esta ampliação está além da capacidade das pontes, subentende-se que os projetistas têm em vista a construção de uma quarta ponte. Conclui-se, portanto, que parte dos técnicos e executivos das instituições de planejamento e execução de infraestruturas e serviços de transportes na RMF operam no quadro de um planejamento conservador e na medida em que, ciclicamente, há recursos carreados a esses organismos, cristalizam, no espaço, esse conservadorismo. 


\section{Conclusões}

O presente artigo objetivou analisar problemas centrais ao planejamento dos transportes públicos e da mobilidade na Região Metropolitana de Florianópolis. Concluímos que as questões essenciais atinentes à qualidade dos transportes e da mobilidade na região, concernem às instâncias sociais do espaço, ou seja, ao arcabouço institucional, normativo, político e social defasados, que se desenvolvem a um ritmo aquém das forças produtivas e dos desafios impostos pelo complexo espaço regional da RMF. Essa complexidade é marcante, pela presença de morros, dunas, mangues, baías, formações lacustres, entre outras. Também destacamos a importância da estruturação regional histórica, que conferiu à Ilha de Santa Catarina a condição de espaço principal de convergência de fluxos cotidianos. Concluímos também, que devido ao tardio desenvolvimento de transportes públicos por ônibus e o abandono dos demais modais de transporte, tais como o marítimo, o ferroviário, e os modos não-motorizados, o automóvel privado tem dominado a matriz modal regional. A estagnação tecnológica e organizacional do setor também é nítida e relaciona-se à ocupação do Estado e suas instituições por elementos conservadores da formação sócio-espacial.

Também destacamos ao longo do texto, diversos exemplos do avanço de uma visão neoliberal que captura o Estado, substituindo-o em processos-chave. Essas abordagens, encabeçadas por agentes da iniciativa privada, acabam por influenciar os rumos das políticas de transporte público e mobilidade na RMF. É o que ocorreu na ocasião das PMIs organizadas pelo Estado de Santa Catarina e o estudo Plamus. Como analisamos nesse trabalho, interlocutores de grupos privados de transporte posicionavam-se entre os agentes públicos organizadores das PMIs e as Prefeituras da RMF, buscando aproveitar-se de governanças locais mais frágeis, para vender seus produtos. A região carece, portanto, de uma instituição de coordenação efetivamente funcional, capaz de integrar as políticas de infraestrutura, de serviços de transporte e de mobilidade da região metropolitana. Mas mesmo depois da criação da Suderf - instituição que deveria ocupar essa lacuna institucional -, o que se observou (e ainda se observa) é que as obras em transporte e mobilidade seguem sendo concebidas e executadas por órgãos estritamente ligados à produção de infraestrutura de transporte e sob uma abordagem na qual os espaços adjacentes são meramente conectivos. Esse é o caso de trechos das rodovias estaduais e federais absorvidas pela mancha urbana na ilha e na área continental da RMF. Como vimos analisando, segue-se ampliando essas vias no sentido de garantir a velocidade em detrimento à mobilidade.

Destarte, cabem, no caso da RMF, tanto proposições técnicas, como proposições relacionadas a inovações institucionais. No que se refere à tecnologia de transporte empregada e ao planejamento urbano, a implementação de tecnologias de transporte mistas se adequa melhor às características da região. Nesse caso, catamarãs (transporte coletivo marítimo) podem ser empregados para efetuar travessias marítimas, paralelamente à acessibilidade continente-ilha conferida pelas Pontes Pedro Ivo Campos e Colombo Machado Salles. Em uma implantação posterior, o sistema marítimo pode se estabelecer no Norte da Ilha, entre os espaços insulares de Jurerê, Canasvieiras e Santo Antônio de Lisboa, estabelecendo conexão com os espaços continentais de Biguaçu e Governador Celso Ramos. Ao Sul, o mesmo sistema poderia interconectar os espaços continentais ao Sul de Palhoça e Paulo Lopes, com a rodovia SC-405, o Aeroporto Hercílio Luz e o Campeche, no Sul da Ilha. Tal conformação possibilitaria uma interação circular regional, intercalando trechos marítimos e trechos terrestres, evitando que todos os fluxos continente-ilha se afunilem entre as Pontes Pedro Ivo Campos e Colombo Machado Salles. Esse pode ser o futuro a ser perseguido em termos de planejamento dos transportes urbanos regionais.

Obviamente seriam necessários também, novos sistemas para a superfície insular e continental, capilarizando a acessibilidade em terra. Nesse caso, tornam-se necessários 
estudos em maior profundidade, para que se possa averiguar com precisão quais são os eixos e áreas de maior ou menor dispersão da demanda. De todos modos, em quaisquer contextos, seria possível combinar um sistema BRT a linhas de VLT, sendo o BRT melhor adequado a espaços mais amplos, dispersos e com sistema viário mais alargado e os VLTs, a espaços mais estreitos, de urbanização antiga e amplo fluxo de pedestres. Os VLTs, nesse caso, efetuariam com maior eficácia os trajetos que perpassam o Centro de Florianópolis e bairros de maior densidade e mescla de usos do solo, como Santa Mônica e Trindade (também em Florianópolis), assim como os bairros Campinas e Kobrasol em São José. A própria Ponte Hercílio Luz - já restaurada - poderia servir de infraestrutura de ligação continente-ilha, acomodando o sistema VLT. Vale ressaltar que na Europa, os sistemas Bus High Level Service (BHLS), os quais são equivalentes ao $\mathrm{BRT}$, são empregados apenas em espaços periféricos, aonde os sistemas sobre trilhos mostram-se demasiadamente antieconômicos.

Além disso, os VLTs são elétricos, empregam um fator de produção relativamente abundante e de menor impacto ambiental, mostrando-se menos submetido às oscilações de preços como é o caso dos derivados do petróleo. Além disso, não formam barreiras geográficas no espaço urbano; fomentam a indústria ferroviária nacional e estimulam a requalificação do entorno urbano em usos mistos. Ademais, são mais confortáveis e confiáveis, incentivando, assim, ampliações das interações espaciais, por diferentes segmentos sociais e, inclusive, retirando automóveis das ruas mais facilmente que o ônibus. Essas novas tecnologias de transporte - VLT, VLP, transporte marítimo moderno etc. - são paradigmáticas no que concerne aos valores do Novo Urbanismo e ao mesmo tempo, podem participar da conversão de uma matriz de empregos muito atrelada à indústria automobilística, para uma indústria ferroviária nacional moderna.

Entretanto, a abordagem dos órgãos de planejamento da RMF tem sido conservadora do ponto de vista das necessidades da região e do próprio espaço construído, que não comporta sistemas demasiadamente consumidores de espaço. Vale ressaltar que os BRTs, a partir de determinado patamar de demanda, necessitam ocupar mais espaço para manter sua eficácia, com faixas de rolamento para adiantamento de paradas, novas estações etc. Nesse contexto, as instâncias de planejamento da RMF mostram-se distantes de um planejamento estratégico urbano, posicionando-se no quadro das ideologias do liberalismo de mercado, pautando-se no custo de implantação imediato dos projetos. A opção por estruturar o transporte público da região a partir de sistemas unicamente baseados em ônibus, também se relaciona à presença de um corpo de técnicos e planejadores frágeis em qualidade e quantidade, que incorporam abordagens de mercado presentes nas consultorias privadas, as quais apenas deveriam auxiliar o Estado na elaboração de estudos. Outro aspecto essencial ao bloqueio de novas tecnologias e readequações institucionais refere-se à visão de curto prazo do próprio empresariado de ônibus, que conforma uma estrutura conservadora de poder. Estes entendem que um novo modal seria danoso à sua eficiência econômica, dado que substituiria os ônibus nos eixos mais densos.

Na realidade, embora a curto prazo possa ocorrer uma transferência de demanda aos sistemas mais eficazes, a médio e longo prazos o que ocorre é que com uma maior diversidade tecnológica, há um aumento na frequentação de passageiros ao sistema de transporte público como um todo. Ademais, quando se introduz uma nova tecnologia com grande capacidade de atrair usuários, podem ser criados subsídios para apoiar os capitais operadores de ônibus até que haja uma acomodação da demanda. Além disso, não basta que se constituam novas autarquias de planejamento, sem que hajam recursos contínuos destinados às mesmas. Inclusive, para que possam, através destes recursos, persuadir outras administrações para que cedam atribuições.

No que se refere às instituições de planejamento, a principal proposição é a da criação de capacidades de investimento por parte dessas instituições. O fato contundente é 
que ações como treinamento contínuo de planejadores; planos de carreira atraentes; redes de benchmarking com outras instituições; uma práxis de concertação interinstitucional e; capacidade de persuasão sobre outras administrações; são elementos que direta ou indiretamente exigem capacidade de investimento em recursos humanos. $\mathrm{O}$ próprio planejamento participativo exige recursos para a organização eficaz e contínua das rodadas de participação. O que se propõe, nesse sentido, é um esforço de geração de recursos destinados à composição de um quadro quantitativa e qualitativamente capaz de levar a cabo esta tarefa no complexo espaço da RMF, dotando-o, inclusive, de ferramentas institucionais adequadas para esse fim.

Obviamente que tais objetivos não podem ser realizados dentro de uma abordagem que isola a cidade das demais escalas de poder do Estado. O sucesso dessas proposições passa pela alta política, alicerçada no engajamento e mobilização popular. Assim, somente um projeto de desenvolvimento nacional - que supere a dependência com relação aos platôs dos ciclos de preços das commodities - pode trazer as condições financeiras necessárias para a requalificação geral da acessibilidade e da mobilidade das cidades e regiões metropolitanas latino-americanas. Não se trata de reeditar as já superadas formas centralistas de planejamento, mas de garantir os recursos necessários ao planejamento democrático, isto é, à perenização da prática desse planejamento.

AGRADECIMENTOS: O presente trabalho foi realizado com apoio do CNPq, Conselho Nacional de Desenvolvimento Científico e Tecnológico - Brasil ( $n^{\circ}$ do processo 154329/2018-5), 2018-2019 e durante a vigência das bolsas DS/CAPES, Conselho Nacional de Desenvolvimento Científico e Tecnológico - Brasil, entre 2013 e 2016 e a Bolsa PDSE/CAPES (processo n. 654513-0), entre 2013 e 2015. 


\section{Q Bibliografia}

" Ascher, F. (2010). Os novos princípios do urbanismo. São Paulo, Romano Guerra.

» Autoridade dos Transportes Metropolitanos - ATM. (2013). Memòria 2012. Barcelona.

»Banister, D. (2008). The sustainable mobility paradigm. Transport Policy vol. 2 no 15, p. 73-8o. <http://dx.doi.org/10.1016/j.tranpol.2007.10.005>.

» Brasileiro, A. e Henry, E. (1999). Viação Ilimitada. Ônibus nas cidades brasileiras. Cultura Editores Associados.

»Campos, N. J. de. (1991). Terras comunais na llha de Santa Catarina. Florianópolis, Editora da UFSC.

»Cervero, R. e Dai, D. (2014). BRT TOD. Leveraging transit oriented development with bus rapid transit investments. Transport Policy 36,127-138. <http://dx.doi. org/10.1016/j.tranpol.2014.08.001>.

»Cheptulin, A. (1982) A dialética materialista. Leis e categorias da dialética. São Paulo, Alfa-Ômega.

" Cocco, R. G. (2017) Transporte público e mobilidade na Região Metropolitana de Florianópolis. Florianópolis, Insular.

»Consórcio Regional de Transportes de Madrid. (2013). Informe estadístico anual. Madri: BOCM.

»Departamento Nacional de Transito. (2018). Dados estatísticos. Brasília. <http:// www.denatran.gov.brl.>

"Empresa Brasileira de Planejamento de Transportes Geipot. (1978). Estudo sobre Transportes Urbanos para a Grande Florianópolis (ETURB). Florianópolis.

» Farmer, S. (2011). Uneven public transportation development in neoliberalizing Chicago, USA. Environment and Planning, 43 (5), 1154-1152. <http://www.envplan. com/abstract.cgi?id=a43409. $>$.

"Figueroa, O. e Orellana, A. (2007). Transantiago. Gobernabilidad e institucionalidad. Revista Eure 32 (100), 165-171. <http://dx.doi.org/10.4067/ So250-71612007000300010>.

" Gramsci, A. (1968). Os intelectuais e a organização da cultura. Rio de Janeiro, Civilização Brasileira.

»Gramsci, A. (2004). Escritos Políticos. Rio de Janeiro, Civilização Brasileira.

»Gutiérrez, A. (2012) ¿Qué es la movilidad? Elementos para (re) construir las definiciones básicas del campo del transporte. Bitácora 21, (2), 61-74.

» Instituto Brasileiro de Geografia e Estatística. IBGE. (2010). Censo de 2010. Brasília. <http://cens02010.ibge.gov.br/resultados.html.>.

» Jaramillo, S. (1983). Crisis de los medios de consumo colectivo urbano y capitalismo periférico. Desarrollo y Sociedad 12, (3), 127-145, <http://www. scopus.com/record/display.url.>.

" Lindau, L. A., Hidalgo, D. e Lobo, A. de A. (2014) Barriers to planning and implementing Bus Rapid Transit systems. Research in Transportation Economics 48, 9-15. http://dx.doi.org/10.1016/j.retrec.2014.09.026. 
» Lindenau, M. e Böhler-Baedeker, S. (2014) Citizen and stakeholder involvement. A precondition for sustainable urban mobility. Transportation Research Procedia 4, 347-36o. http://dx.doi.org/10.1016/j.tranpol.2007.10.005.

» Lobo, M. L. C e Simões Júnior, J. G. (2012). Urbanismo de colina. Uma tradição luso-brasileira. São Paulo, Mackenzie.

» Logit Engenharia Consultiva. (2014). Case studies. São Paulo. <http://www. logiteng.com/case-studies/.>.

» Logit Strategy et al. (2015). PLAMUS Plano de Mobilidade Urbana Sustentável da Grande Florianópolis. Florianópolis. <http://www.bndes.gov.br/SiteBNDES/bndes/>.

" Mackinnon, D., Shaw, J. e Docherty, I. (2010). Devolution as Process. Institutional Structures, State Personnel and Transport Policy in the United Kingdom. Space and Polity, 43, (5), 1154-1172. http://www.envplan.com/abstract.cgi?id=a43409.

» Marx, K. (2011) Grundrisses. Elementos fundamentais para a crítica da economia política. São Paulo, Boitempo.

»Miralles-Guasch, C. e Cebollada-Frontera, A. (2003). Movilidad y transporte. Opciones políticas para la ciudad. Madrid, Fundación Alternativas.

»Miralles-Guasch, C. (2002). Ciudad y transporte. El binomio imperfecto. Barcelona, Ariel.

»Paget-Seekins, L. (2015). Bus rapid transit as a neoliberal contradiction. Journal of TransportGeography 48,115-120. http://dx.doi.org/10.1016/j.jtrangeo.2015.08.015.

"Peluso Júnior, V. (1991). Estudos de Geografia Urbana de Santa Catarina. Florianópolis, Editora da UFSC.

"Portelli, H. (1977). Gramsci e o Bloco Histórico. Rio de Janeiro, Paz e Terra.

"Rangel, I. (2005). Obras reunidas. Rio de Janeiro, Contraponto.

» Røe, P. G. (2000). Qualitative research on intra-urban travel: an alternative approach. Journal of Transport Geography, 8 (2), 1-31.

»Santos, M. (1982). Sociedade e espaço. A formação social como teoria e como método. Boletim Paulista de Geografia, 54, São Paulo.

»Seguí-Pons, J. M. e Martínez-Reynés, M. R. (2004). Geografía de los Transportes. Palma, UIB.

» Silva, C. M. (1992). Ganchos-SC. Ascensão e decadência da pequena produção mercantil pesqueira. Florianópolis, Editora da UFSC.

» Sugai, M. I. (2002). Segregação silenciosa. Investimentos públicos e distribuição sócio-espacial na área conurbada de Florianópolis. Tese de Doutorado em Arquitetura e Urbanismo, Universidade Federal de Santa Catarina.

"Vasconcellos, E. A. (2014) Políticas de transporte no Brasil. A construção da mobilidade excludente. Barueri, Manole.

\section{Rodrigo Giraldi Cocco / rodrigog.cocco@gmail.com}

Graduado e Mestre em Geografia (Universidade Estadual Paulista), Doutor em Geografia (Universidade Federal de Santa Catarina e Universidade Autônoma de Barcelona). Integrante do Grupo de Estudos em Desenvolvimento Regional e Infraestruturas (Gedri, Florianópolis), do Laboratório de Circulação, Transportes e Logística (Labcit/UFSC) e do Grupo de Estudos em Mobilidade, Transporte e Território (GEMOTT, Barcelona). 